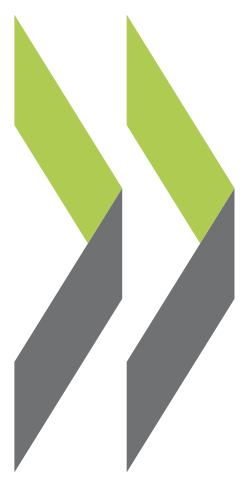

SIGMA Papers No. 38

Political Advisors and Civil Servants in European OECD Countries 
Organisation de Coopération et de Développement Economiques

Organisation for Economic Co-operation and Development

28-Mar-2007

PUBLIC GOVERNANCE AND TERRITORIAL DEVELOPMENT DIRECTORATE

English - Or. English

\begin{abstract}
SIGMA - A JOINT INITIATIVE OF THE OECD AND THE EUROPEAN UNION, PRINCIPALLY FINANCED BY THE EU
\end{abstract}

\title{
POLITICAL ADVISORS AND CIVIL SERVANTS IN EUROPEAN COUNTRIES
}

SIGMA PAPER NO. 38

While defining appropriate roles for political advisers is a highly relevant topic in most democracies and especially in EU NMS, as well as candidate and CARDS countries today, surprisingly little comparative information exists.

To fill this gap, in Autumn 2005, the Sigma Programme launched a questionnaire-based study to collect country experience, as well as a series of seminars on the topic. The first part of this publication provides an overview on the role of political advisers and their relationship with civil servants in OECD countries. In a second part, detailed country chapters on political advisers in Denmark, Poland, Portugal, Spain, as well as Great Britain are presented.

For further information please contact Ms. Anke Freibert, Sigma; Tel: (33 1) 45241399 - Email: anke.freibert@oecd.org 

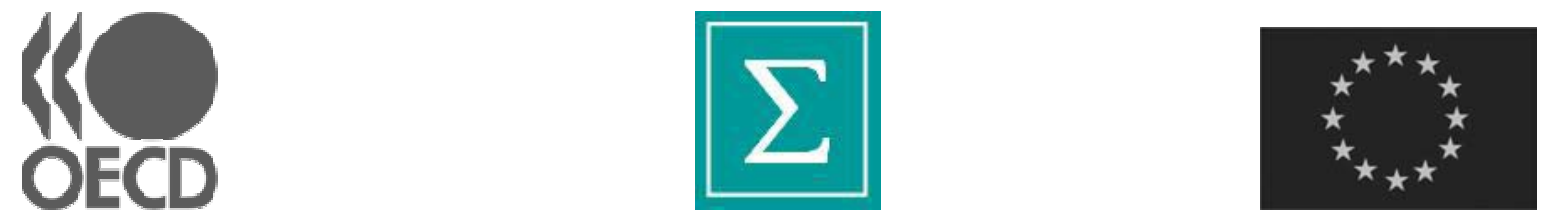

\title{
SIGMA
}

Support for Improvement in Governance and Management A joint initiative of the OECD and the European Union, principally financed by the EU

\section{Political Advisors ANd Civil Servants IN EUROPEAN COUNTRIES}

\author{
Sigma PAPER No. 38
}

Prepared for Sigma by Simon James

with country chapters by Thomas Broeng Jørgensen and Rikke Ginnerup (Denmark), Jacek Czaputowicz (Poland), José Alexandre Guimarães de Sousa Pinheiro (Portugal), Antonio Natera-Peral and Francisco Javier Ruiz-Martínez (Spain), as well as Katharine Raymond (United Kingdom)

This document has been produced with the financial assistance of the European Union. The views expressed herein are those of the author and can in no way be taken to reflect the official opinion of the European Union, and do not necessarily reflect the views of the OECD and its Member countries or of the beneficiary countries participating in the Sigma Programme. 


\section{THE SIGMA PROGRAMME}

The Sigma Programme - Support for Improvement in Governance and Management — is a joint initiative of the Organisation for Economic Co-operation and Development (OECD) and the European Union, principally financed by the EU.

Working in partnership with beneficiary countries, Sigma supports good governance by:

- $\quad$ Assessing reform progress and identifying priorities against baselines that reflect good European practice and existing EU legislation (the acquis communautaire)

- $\quad$ Assisting decision-makers and administrations in setting up organisations and procedures to meet European standards and good practice

- $\quad$ Facilitating donor assistance from within and outside Europe by helping to design projects, ensuring preconditions and supporting implementation.

In 2007 Sigma is working with the following partner countries:

- $\quad$ New EU Member States - Bulgaria and Romania

- $\quad$ EU candidate countries - Croatia, the former Yugoslav Republic of Macedonia and Turkey

- Western Balkan countries - Albania, Bosnia and Herzegovina (State, Federation of BIH, and Republika Srpska), Montenegro, Serbia and Kosovo (governed since June 1999 by the UN Interim Administration Mission in Kosovo - UNMIK)

- $\quad$ Ukraine (activities financed by Sweden and the UK).

The Sigma Programme supports reform efforts of partner countries in the following areas:

- Legal and administrative frameworks, civil service and justice; public integrity systems

- $\quad$ Public internal financial control, external audit, anti-fraud, and management of EU funds

- $\quad$ Public expenditure management, budget and treasury systems

- Public procurement

- Policy-making and co-ordination

- Better regulation.

For further information on Sigma, consult our web site: http://www.sigmaweb.org

\section{Copyright OECD, 2007}

Application for permission to reproduce or translate all or part of this material should be made to: Head of Publications Service, OECD, 2 rue André Pascal, 75775 Paris Cedex 16, France. 


\section{FOREWORD}

While defining appropriate roles for political advisers is a highly relevant topic in most democracies and especially in EU NMS, as well as candidate and CARDS countries today, surprisingly little comparative information exists. To fill this gap, in autumn 2005, the Sigma Programme launched a questionnaire-based study to collect country experience.

In January and February/ March 2006, the Sigma Programme, jointly with the OSCE Mission in Kosovo, Public Administration International (PAl) and the Office of the Prime Minister of Kosovo organised two series of seminars on the role of political advisers and senior civil servants. The goal of these seminars was to promote a clearer understanding of the respective roles of civil servants and political advisers at Kosovo ministries and to find ways to clarify and strengthen working relations. During seminars, different European perspectives (Lithuania, Great Britain, Poland and Sweden) on the roles of political advisers and civil servants were presented and debated in discussions and workshops.

The first part of this study provides an overview on the role of political advisers and their relationship with civil servants in OECD countries, also benefiting from insights gathered during the seminars held in Kosovo. In a second part, detailed country chapters on political advisers in Denmark, Poland, Portugal, Spain, as well as Great Britain are presented.

The target audience for this publication is primarily government offices/secretariats and ministries in countries in the CARDS region, but the publication could prove useful to other transition countries currently in the process of improving the functioning of their ministries. The study will feed into an ongoing process of training civil servants/ political advisers in target countries providing an international perspective.

All Sigma publications are available on the Sigma website. 


\section{TABLE OF CONTENTS}

THE SIGMA PROGRAMME




\section{EXECUTIVE SUMMARY}

The tension between political advisors and civil servants is inherent in democratic administrative structures. How do countries define appropriate roles for political advisers and civil servants as rooted in their history? What regulations govern their respective functions? How do political advisers and civil servants cooperate? What are points of contention and how are disagreements resolved? Are there national innovations, also with regard to training? The aim of this questionnaire-based study is to present a variety of national traditions regarding the roles and responsibilities of political advisers and civil servants, as well as the institutional arrangements put into place to mediate inbuilt sources of conflict.

\section{Main Findings Overview:}

- $\quad$ Relations between political advisers and civil servants tend to be problematic in most EU and OECD member states. Frictions occur particularly in a transition context and in those countries with long standing civil services where political advisers are newly introduced.

- $\quad$ Civil servants and political advisers have different, yet complementary roles: They share responsibility in policy advice, as well as loyalty to the minister. Political advisers give advice on policy under the aspect of politics. The civil service is tasked with administration, execution and policy implementation - but also to develop policy options for the minister.

- Political advisers have to rely on the collaboration of the body of civil servants. In return, civil servants often learn that political advisers can help civil servants to understand the political environment in which they operate in.

- $\quad$ Boundaries between political advisers and civil servants should be clearly understood and respected, but these constitute a line, not a wall. Ministries cannot work effectively unless the two groups work together.

\section{Main Findings Country Chapters:}

- In Denmark, the civil service (a merit bureaucracy and a career system in which politically neutral senior civil servants are mainly recruited from within the ministry) can and does provide both policy, as well as politico-strategic advice, yet refrains from engaging in party politics. Per ministry, only one political adviser to the minister is allowed, dealing mainly with the press, rather than providing tactical advice to the minister. A 2004 While Paper further clarifies respective roles and responsibilities and a training course, mandatory for incoming political advisers is supposed to prepare them for working in a ministerial environment.

- In Poland, the separation between the political and the civil service sphere has been hard to achieve and to maintain. Poland adopted a system of political cabinets governed by individual ministerial directives where political advisers and civil servants work together giving political advice to decision makers. A comprehensive regulation concerning political cabinets would be useful, especially given the very negative public opinion towards political advisers which in the past have often become embroiled in political scandals entailing abuse of office.

- $\quad$ Portugal legally defines political advisers in both parliament and government as distinct from civil servants, prohibiting any direct interference in the activity of administrative bodies. However, a large percentage of the political staff working with members of the government is recruited from within the public administration, to which a return is possible, as a civil servant does not have to resign to work as political adviser. This makes a clear separation between political advisers and civil servants de facto difficult. 
- In Spain, four trends - political and administrative decentralisation, consolidation of the welfare state, EU integration and privatisation and outsourcing of public services - have profoundly impacted the role of civil servants at the central level, together with their responsibility to provide political-tactical advice and technical assistance to politicians at different levels of the central administration. Currently, about $3 / 4$ of adviser positions are filled with civil servants. Together with permanent civil servants, political appointees operate in political cabinets as special advisers. In recent years, there have been attempts to formulate a code of ethics, as well as to regulate the recruitment and selection of special advisers, whose numbers are growing rapidly at the local and to some extent autonomous region-level.

- In the United Kingdom, civil servants and political advisers work closely together based on the understanding that ministers depend on a very wide range of advice, both practical and political, to make the best decision based on all available facts. Cooperation between the two groups largely depends on individual professionalism and the understanding that both parties serve common goals. Political advisers are seen as temporary civil servants, required to conduct themselves in accordance with a Code of Conduct for Special Advisers and with the Civil Service Code stressing integrity and service to the currently elected government.

\section{Recommendations:}

- $\quad$ Respective roles of civil servants/ political advisers should be clearly specified, ideally in legislation and backed up with codes of conducts.

- $\quad$ Simple mechanisms are needed to allow for proper and sensible working relationships between the two groups:

A clear understanding that political advisers advise the minister and do not give orders to civil servants

An agreement of what a minister wants to achieve and what each party has to do to reach set goals

Simple working arrangements, such as for example weekly meetings between senior civil servants and political advisers to share information and to allocate work

- $\quad$ Ethical rules are needed to supplement the legal framework. These should be reinforced through HR policy and training measures for all staff.

- Mechanisms to sanction breaches of legislations need to be put in place. Investigation and punishment rules for political advisers are surprisingly absent in Western European countries. 


\title{
I - COMPARATIVE STUDY
}

\section{POLITICAL ADVISORS IN EUROPEAN COUNTRIES: A COMPARATIVE STUDY}

\author{
Simon James \\ Sigma Consultant
}

Political advisors are not an entirely new phenomenon in Western Europe, but they have been adopted by an increasing number of countries in recent decades, and in countries where they are well established, their numbers have tended to increase. This has led to debate about their purpose, their relationship to ministers and to the civil service, their effectiveness, and the legal and ethical framework within which they should operate. This paper reviews these issues, and considers what lessons may be drawn.

Surprisingly little has been written about political advisors. This paper draws on a number of studies commissioned by Sigma for this publication, the limited literature available, information provided by civil servants in a number of European countries, and direct personal knowledge. The result is an aggregate; it is possible to identify at least one exception to many of the statements that follow. While there is considerable variation between the political advisor arrangements existing in different countries, there is nevertheless sufficient common practice to allow some general observations to be made and conclusions drawn.

This paper is written in the context of the concept, now widely accepted, of a "European standard" of civil service, described in other Sigma papers, notably European Principles for Public Administration and Civil Service Legislation Contents Checklist - the key principle being, in this context, the political impartiality of the civil service. That in itself is not a simple concept, since all civil servants work for politicians and are involved in the essentially political task of distributing public resources. Many countries accord their civil servants the function of giving politico-tactical advice and support to their ministers. Despite this, it is clear from the daily practice of many European countries that it is possible for civil servants to act in a non-partisan but politically sensitive manner.

Most European political systems also make provision for political advisors to members of the legislature, or at least to its leading members, or to its main political parties. Some countries also make provision for political advisors in regional or municipal government. Many of the issues covered in this paper also apply to advisors in these other branches of government, but this paper deals only with political advisors to government ministers.

\section{Defining "Political Advisors"}

Political advisors are best defined in relation to the two groups with whom they work most closely: ministers and civil servants. They are assistants to ministers, to whom they offer advice and support, usually of a political nature. Their appointment is essentially an "appointment of trust", which is personal to the minister and lasts only as long as he/she holds office. Political advisors can be distinguished from the minister's personal support staff (who in some countries are also non-civil service appointments), who are responsible for schedule-keeping, logistical support and similar matters. The distinctive function of political advisors is to offer advice.

Political advisors differ from regular civil servants in three crucial respects. First, since they are personally nominated by the minister, they are exempt from the usual civil service entry requirements (although sometimes they may previously have served as civil servants). 
Otherwise, there is rarely any qualification required for appointment as a political advisor. Ministers obviously look for people of competence, although it has to be said that considerations of political affiliation sometimes take precedence over this. Second, they stand outside the normal hierarchy of the ministry. Usually they are responsible only to the minister and take their instructions from him/her. Third, they are exempt from the requirement imposed on civil servants to act with political impartiality; the whole point of a political advisor is, precisely, that he/she can give politically loaded advice that the minister cannot request of the civil service.

The legal position varies: in some countries, political advisors are treated as a special category of civil servant, whereas in others they are specifically excluded from the ambit of the civil service law; in some their position is uncertain. The country papers that follow give a variety of examples of legislation governing the issue. Poland has extensive regulation, although there are variations between ministries as far as the functions of political advisors are concerned. In Sweden and the United Kingdom, political advisors are a clearly defined, separate category of public employees, but otherwise legislative provision is minimal. Strongly accepted "norms" have sufficed to make the innovation work - although in the United Kingdom in the past decade these norms have proved inadequate and are increasingly supplemented with quasi-legislative arrangements, such as a code of conduct and standard employment contracts. In Portugal and Spain, as the country papers in this publication show, the absence of legislation or norms clearly creates serious difficulties, and as a consequence Spain is moving towards regulation. In France, legislative restrictions are frequently overridden by politically accepted norms of behaviour.

It is not possible to treat the role of the political advisor in isolation. What the political advisor does is to a large degree conditioned by the functions of the civil servants alongside whom he/she works. There are three possible models:

- $\quad$ Political advisors working alongside a politically neutral civil service (Denmark, Sweden, the United Kingdom): In this system the civil service is usually the dominant element in advising and supporting the minister, and the role of the political adviser is confined to offering a separate stream of political counsel.

- $\quad$ Political advisors working alongside a civil service of which the top tier is also politicised: This creates a more muddled system, as the Spanish country paper shows.

- $\quad$ Cabinets ministériels (France, Italy, until recently Belgium), consisting usually of a mixed group of political advisors and civil servants on temporary secondment, who both advise the minister and exercise strong control over the ministry in his/her name: In such systems there is usually some distance between the minister/cabinet and the civil servants who make up the remainder of the ministry.

In all of the countries whose experience is reflected in this paper, three basic questions arise when considering the relationship between political advisors and civil servants.

First, whether the political advisor has the right to issue instructions to civil servants: In most countries, he/she does not, because (a) it would interfere in the civil service chain of command and accountability and expose civil servants to pressures to breach their political neutrality; and (b) the role of an advisor is to advise - in this case specifically to advise the minister - not to command. (Controversy recently arose in the United Kingdom over proposals to allow political advisors to "communicate" ministers' instructions to civil servants, since there was a fear that political advisors might add their own gloss to those instructions.)

Second, whether a demarcation of functions between the two categories of staff is needed: Where the boundary is drawn between them is a secondary (although important) issue; the essential requirement is that there should be a boundary that is understood and respected by both groups. (The author's experience of working with eastern European countries is that a 
misunderstanding each other's role and the absence of such a boundary and working relationship usually lie at the heart of frictions between political advisors and civil servants).

Third, whether the two groups can develop a good working relationship that allows the crossing of that boundary without compromising the role of either group: This applies particularly to the role that each should play in policy formulation. In some countries, there is a tendency to confine civil servants to a more legal and technical role; amongst the country studies that follow, that tendency comes out most clearly in the study from Portugal. In a number of eastern European countries this has been taken to an extreme, due to a tendency to equate "policy" with "politics" and to exclude the civil service from both. This is not, on the whole, a constructive tendency. It causes the burden of policy-making to fall on a small number of political advisors, who consequently become overburdened, while the civil service is underused by being confined to tasks of administration and implementation. It also means that policy is being made in isolation from the experience of its implementation; the absence of a "feedback loop" is a serious weakness in a policy-making system.

\section{Numbers, Role, Recruitment and Background}

Data on the numbers of political advisors in European countries is surprisingly difficult to obtain, even in countries with open government. The rule in most European countries, however, seems to be that most ministers are allowed one, two or three advisors, with the common exception of the prime minister, who is often allowed a larger number. Regulations setting a limit on the number of advisors seem rare, although the reasons vary greatly between countries. In the United Kingdom, the government resists the imposition of any limit, which has allowed an expansion to some 25 advisors in the Prime Minister's Office and 10 in the Ministry of Finance, although in most ministries only two advisors remains the norm. In Denmark, on the contrary, the government has resisted recommendations from an external commission to set a limit of two or three advisors, since the government wants to preserve the existing limit of one per minister. In cabinet systems the figures are much higher: limits exist in France and are routinely ignored. Spain has an oddly asymmetrical arrangement, with between 4 and 11 in most ministries, but 69 in the Prime Minister's Office and 106 in the Ministry of Public Administration.

In reality, the main restriction on the number of advisors appears to be public tolerance rather than legislation. In Poland, criticism has led to restrictions, and in Spain and the United Kingdom it seems to have braked the expansion of numbers. The number of political advisors can also be affected by more general criticisms of the administrative system; attempted reforms in Belgium and Italy have been the consequence of public scandals over wider issues of administrative failure or corruption.

By definition, a political advisor will be expected to have strong political affinities with the minister for whom he/she works. This does not necessarily mean that he/she must be a member of the minister's party - although usually that is the case - but the advisor must be sufficiently in tune with the minister's views to ensure that the advice provided accords with the minister's general political outlook and values.

The practice, occasionally encountered, of appointing a political advisor from one party in the coalition to "keep an eye" on a minister from another coalition party is inherently unstable and usually leads to tension and destructive dynamics.

Within these limitations, there are three main types of advisor: the expert, the generalist, and the press aide. The experts are usually in the minority. They are recruited because of their knowledge or experience of a particular issue of importance to the minister. They usually have a relevant professional background or academic specialisation, and are often in the middle or at the end of their career. They will tend, within the ministry, to focus fairly narrowly on these areas, 
although they are commonly asked to "take an interest" in other areas as well. (In transition countries of Eastern Europe, a common phenomenon in recent years has been a relatively high proportion of expert advisors, brought in to compensate to some extent for a deficiency of policy-making capacity in the evolving civil service).

The generalists are usually the majority. They may have some experience in the ministry's subject area, but are recruited mainly as political aides de camp. They are often young, and their backgrounds tend to be as political party employees, journalists, lawyers or academics.

The press assistants are numerically fewer and are found only in some countries (Denmark is unusual in that its political advisors concentrate mainly on press affairs). There is an overlap between this category and the generalists, since many of the latter will, as part of their general assistance to the minister, spend some time briefing the media on behalf of their ministers. To a large extent their activities will be defined by the presence or absence of a civil service press office in the ministry, and whether the minister has confidence in it.

Since the selection of political advisors is personal to each minister, recruitment is often unsystematic and random, almost always undertaken through informal political contacts. It seems to be rare for political parties to try to identify potential advisors for their ministers, although on occasion a party employee may be suggested as a candidate. It is usually left to ministers themselves and, one can assume, ministers prefer to keep control over their selection.

To what extent has a "profession" of political advisors developed? In most countries, for most post-holders it is an interesting and unusual interlude in their careers; when their minister loses office, the advisors usually return to their previous careers. Sometimes a political advisor will follow a politician from one ministerial appointment to another. Occasionally, an advisor might stay in the same ministry under several successive ministers of the same party, especially if he has some particularly valuable expertise. Occasionally an advisor might be recruited to work amongst the prime minister's advisors (further discussion of this group of advisors is provided below). In some countries such a posting may form part of a longer-term political career; in France one or several spells as a ministerial advisor or cabinet member is a more or less essential stage in the upward progress of a politician or senior civil servant, while in Great Britain a growing proportion of members of parliament and ministers have previously served as political advisors (including, at the time of writing, the Foreign Minister and the Leader of the Opposition). Being a political advisor seems to have become a profession only in cabinet systems, such as in France, where promotion to cabinet membership is effectively the main pass key to political promotion for civil servants (see the section on cabinets below). In Belgium, until recent changes, studies show that members of ministerial cabinets tended to remain in post longer than the ministers they served, becoming as a consequence a more durable influence on the policy areas in which they were working than the ministers themselves. Ireland shows a different variant on this pattern, where the development of funding for opposition parties has created a "revolving-door" pattern, in which political advisors whose ministers have lost an election take up party posts and then become ministerial advisors again when electoral fortunes change.

The cost of political advisors is occasionally a contentious issue. It has been controversial in the United Kingdom, where the Blair Government has greatly increased the numbers of advisors since 1997, and it was a factor in causing the Polish Government to cut the number of advisors in 2004. However, when political advisors come under criticism, it seems to be far more often for their role rather than for their cost.

\section{Functions}

Regulations governing the work of political advisors - where they exist - seem to concentrate mainly on their formal legal status and line of accountability, and they do not often seek to define 
what the advisor will do. This definition of functions is left (sensibly enough) to the minister to determine. In practice, the following is a list of functions that a political advisor might be asked to undertake:

- Relations with the party - with party officials, parliamentarians, regional and municipal councillors, party supporters, and possibly political parties in other countries: By definition, this is an area in which civil servants are usually prohibited from supporting the minister.

- Relations with other ministers: Any effective government will have an efficient system for inter-ministerial co-ordination on policy-making and administrative issues, which usually will be operated by civil servants. However, there will be party matters on which civil servants cannot work, and there may be issues of such political sensitivity that the minister will prefer to have them handled by someone he/she trusts very closely. This may particularly be the case in coalition governments, in which inter-party negotiations are needed.

- $\quad$ Speech-writing: Always a laborious and ungrateful task, many "official" speeches can be written by civil servants, but the minister will often want a draft revised to give it a more political inflection, and party speeches will have to be written entirely by advisors.

- $\quad$ Advice on current issues: The minister will want to discuss, and have advice on, immediate pressing political issues - very often on something in that day's media headlines.

- Commentary on proposals prepared by civil servants in the ministry: Sometimes this commentary consists of reviewing these proposals from a political viewpoint and asking the questions that civil servants cannot ask: How will the party react? How will this affect next month's regional elections? More often, this task will consist of reviewing the proposals to see how they fit with the minister's own views and the governing party's priorities: Does the proposal pay sufficient attention to issues of social equality? Is it possible to devise a more market-based solution to the problem? Is the proposal drafted with too much concern for administrative requirements and too little concern for political imperatives?

- $\quad$ Relations with the party's supporters in the legislature: This function involves briefing these supporters on the minister's proposals and prompting them to make helpful interventions in debates or to ask the minister favourable questions.

- Helping the minister to prepare for public appearances - debates in parliament, appearances before committees of the legislature, major speeches or media interviews: Ministers find this easier to do with someone they know well and trust politically.

- $\quad$ Briefing the minister on government proposals outside his responsibilities: The minister may attend meetings of the government or of ministerial committees in which some issues will not affect the interests of his/her ministry but on which he/she may, as a member of the collective government, wish to express an opinion. Since such an intervention is likely to be political in nature, the minister is likely to turn to his/her political advisors for assistance.

- Proposing their own new policy ideas or "working up" ideas by the minister for new initiatives: Civil servants are often cautious and keen to protect their minister from treading on controversial ground. Political advisors, in contrast, can suggest ideas that civil servants might dismiss as outlandish.

- Acting as informal emissary to outside groups: This task involves contacts with influential party supporters, pressure groups, friendly academic organisations or think tanks, business leaders or trade unionists. 


\section{Relations with the Minister}

The position of the political advisor is very similar to that of a courtier serving an absolute monarch: everything turns on the favour or disfavour of one person. Retaining the minister's confidence is crucial.

The essential prerequisite is access. First and foremost, this means access in person to the minister. This requires the advisor to be physically located in an office close to the minister's and to have some claim on the minister's time. The ideal is to have a fixed time each day or several times a week for the advisor and the minister to meet. If the minister has a number of advisors led by a chief political advisor (or a cabinet), it is up to the minister to decide whether to deal with all of the advisors or only with the chief advisor, funnelling all of the advice through him/her. This is no mere managerial detail; it can crucially affect the quality and content of the advice that the minister receives. The determining factor will be the minister's own preference (and possible that of the chief advisor) but in the present author's experience, the most effective approach is a mixed one, in which the minister occasionally meets all of the advisors as a group but also deals directly with an individual advisor who is working on a particular issue. It is important for advisors to understand clearly how the minister is thinking and what he/she wants, and that will be more accurately and effectively conveyed by dealing with the minister directly rather than refracting the message through the chief political advisor. This also adds to the job satisfaction of the political advisor.

Also essential are access to the key meetings that the minister attends, especially with the ministry's civil servants to discuss policy development, and access to the papers forwarded to the minister from the ministry's own staff, from other ministries, and from outside sources. In many countries, disputes over admission to meetings and availability of papers are a cause of frustration to advisors and of friction with civil servants. Friction between political advisors and the official responsible for acting as the minister's "gatekeeper" is quite common. It is highly advisable for the government, as part of the rules governing the functions and operations of political advisors, to specify what is and is not permissible. There have to be exemptions - for instance, most countries deny advisors access to documents classified as high security - but as a general rule the advisor needs to be given free access to meetings and information if he/she is to advise the minister properly.

This access, however, places a reciprocal obligation on the advisor. He/she should make circumspect use of privileged access to the minister, should not take up more of the minister's valuable time than necessary, and when given access to confidential information, should treat it with care and not leak it to outsiders. When attending meetings alongside the minister, he/she would be wise to say little and listen a lot. The most effective advisors are usually those who use their privilege with circumspection. There are enough examples of advisors - often the younger ones - who allow their eminence to go to their head and enjoy their importance too much. This usually sours their relationship with the rest of the world, and particularly with the rest of the ministry, does them no good and can end up irritating the minister. To coin a phrase referring to US presidential advisors, the best of them will have "a passion for anonymity".

Once the necessary access has been established, the day-to-day functions of the advisor will be dictated by the minister's (often changeable) demands. The crucial element is the development of trust. If the minister makes his/her thinking clear to the advisor, and if the adviser acts with circumspection (although not timidity), offering advice that is sensible and politically acute, the advisor will become an indispensable part of the minister's life. At best, as the advisor grows into the role, there develops a process of symbiosis, in which the advisor comes to appreciate the minister's requirements and to understand how his/her mind works. A good advisor will be able to predict the minister's reaction to events and ideas and to anticipate his/her future needs. 
In some European countries a ministry will also have one or more subordinate ministers, who usually do not have political advisors of their own. One would expect that the relationship of subordinate ministers with their minister's political advisors to be a tricky one. Self-evidently, the subordinate minister will regard him/herself as the minister's natural deputy and will expect to be taken into the minister's confidence and to be involved in the major decisions of the ministry. However, many ministers may feel more at ease with a political advisor whom they have selected themselves than with another politician, who may be a rival - possibly from another party in the governing coalition - and who may have been imposed by the prime minister against the minister's inclinations. Surprisingly, however, evidence of such tensions is rare, almost non-existent.

\section{Relations with the Civil Service}

As stated above, the roles of civil servants and political advisors and their assessment of a given situation may differ; these differences, together with the perception by civil servants that political advisors have too prominent a role, may well be a source of tensions. Certainly, when systems of political advisors were introduced in Great Britain and Ireland in the 1970s and 1980s, many (probably most) civil servants viewed them with suspicion, as institutionalised rivals and intrusive nuisances. It is noticeable that in both countries this resentment subsided over time and within five to ten years the innovation was broadly accepted. However, the ease or friction of the relationship varies between countries, between ministries and from individual to individual.

To some extent it is conditioned by the overall relationship between the political class and the civil service. Here a spectrum exists. Pinheiro's description of the relationship in Portugal portrays a considerable degree of polarisation between politician and civil servant, which automatically creates scope for friction. The cabinet systems of France, Belgium and Italy, in which the cabinets have in varying degrees usurped the functions exercised in other countries by the senior civil service, contain the potential for similar frictions, although this varies between ministries, depending on the modus operandi of each cabinet. In Denmark, Spain, Sweden and the United Kingdom, where the civil service has long been accorded a significant policy/tactical role and where the function of political advisors has been more restricted, co-operation has been much easier. Indeed, the United Kingdom (as described in the study), since the great expansion of political advisors in the late 1990s, gives an oddly mixed picture, with accounts of serious clashes between political advisors and civil servants in some ministries and the simultaneous development of a much closer working relationship between the two, where they work together on the elaboration of policy proposals. Such a relationship does not exist even in Sweden.

Potential difficulties in the relationship are legion. At one extreme - alleged in the Portugal study - but fairly rare is the illegal political interference in administrative decisions. More common are difficulties rooted in a difference in outlook. Political advisors are usually more interested in short-term results, officials in long-term consequences. Political advisors are in a hurry; civil servants can afford to give more time to thought. Political advisors have an eye on the electoral dimension, civil servants much less so. Political advisors are apt to be more innovative; civil servants are more cautious, partly by nature, partly because they have to live with the consequences. In addition, beyond question, the introduction of political advisors into a system of decision-making complicates the already complex process of getting a decision out of the government machine.

Overall, however, civil servants in Europe seem to have become habituated to the idea of political advisors. Their appointment has not resulted in the politicisation of the civil service. (Indeed, although the number of OECD countries with political advisors has increased, and the number of political advisors in those countries has risen, a recent OECD survey suggests that in most countries the trend has been towards less political control of the civil service. Political 
advisors have not, on the whole, supplanted civil servants as the main source of policy advice to the minister. As time has passed, they have become an accepted part of the system. It is true that they challenge the monopoly of civil service advice to ministers. However, they are one of the numerous challenges that have arisen in recent decades to the supremacy of the traditional Weberian civil service. The challenge to civil service monopoly of policy advice is paralleled by challenges to the adequacy of civil services in many areas, including economic management, service delivery and the bureaucracy's management of itself. Challenge and contestability have become part of the toolkit of public sector modernisation, and there is no reason for policy formulation to be exempt from these pressures. Indeed, politicians seem to welcome and demand multiple channels of policy advice; political advisors are only one manifestation of this trend and, beyond question, they add to policy advice a political dimension that civil servants are disqualified from offering. The more thoughtful civil servants realise that this added dimension strengthens rather than weakens policy-making (or, at least, increases ministers' satisfaction with the policy-making process).

In two senses, the political advisor can be a help to the civil servant in his/her daily work. First, if the symbiosis between minister and political advisor (described above) does develop, the political advisor can become a valuable source of advice to civil servants. Most civil servants will see their minister only rarely. The political advisor has more time to spare. It is very useful to civil servants to be able to ask the political advisor, "why exactly has the minister asked us to look at this issue?" or "if we put forward a proposal along these lines, how do you think the minister will react?" This sort of "litmus paper" function can be very valuable.

Second, the existence of political advisors can shield civil servants from demands to carry out party political tasks for ministers. In the absence of political advisors, ministers are likely to ask civil servants to assist them with issues that fall outside the civil service boundaries of neutrality, such as helping with preparations for a party meeting, drafting letters to party officials, or brokering agreements between coalition parties. Political advisors were introduced in Denmark in the late 1990s precisely because civil servants were being drawn quite deeply into political work. It was common, for example, for civil servants to attend political party meetings, and they were drawn into inter-party brokering on coalition issues. Pressure from the Folketing (the Danish Parliament) led to the creation of a separate cadre of political advisors to undertake such duties.

However, a wise political advisor will know that he/she needs the civil service more than the civil service needs him/her. The advice given above - that the political advisor should use his/her influence and access with circumspection - applies particularly to dealings with the civil service. In particular, the political advisor should not presume to give orders to civil servants, unless specifically empowered to do so (and in most countries, advisors have no such power). Nor should he/she fall prey to the allied temptation to claim to speak on behalf of the minister - "the minister has told me to tell you to do X" - because in doing so, the political advisor is effectively inserting him/herself into the hierarchical chain of command of the ministry. That will lead to resentment and, quite probably, the day will come when the advisor overreaches him/herself and is disowned by the minister. Unless otherwise empowered by law, the political advisor's sole function is to advise the minister, who in turn should make the decisions and issue the orders.

More generally, the political advisor will obtain the best co-operation from the civil service in just the same way as one gets the best co-operation from anyone: by politeness, professionalism and consideration. If he/she approaches civil servants in a constructive spirit, they are most likely to respond in kind; after all, given his/her close relationship with the minister; their natural instinct will be to help if they can. The state of affairs that the advisor needs to achieve is the "virtuous spiral" of being regarded by civil servants as useful and influential, thereby encouraging civil servants to share problems and information with him/her, which then further increases the ability of the advisor to offer influential advice. 
The political advisor who is arrogant or aggressive will simply alienate people whose co-operation he/she needs. This is asking for trouble, since a civil service that wants to make an advisor's life difficult can do so, in defiance of the minister. It can "forget" to copy papers to the advisor, invite him/her to meetings only at the last minute, withhold basic but vital office services, such as an Internet connection, and cause awkwardness in all sorts of ways. Inevitably, some political advisors fall into a vicious spiral, alienating civil servants and thus depriving themselves of co-operation and information, causing them to lose influence within the ministry and eventually with the minister, which leads to them being further excluded from the ministry's internal debates.

The foregoing seems to imply that success or failure in the relationship is largely in the hands of the political advisor. Beyond question, there is an equal obligation on civil servants to work collaboratively with political advisors, and the common experience across EU countries is that civil servants do co-operate (although there will always be a few awkward personalities who regard political appointees as a personal affront). As a former British political advisor (who in his time had clashed with civil servants) said in a parliamentary debate, "everything depends on the personality, expertise, strength and integrity of the [political] advisor and developing a healthy, honest, professional relationship with permanent officials and ministers".

\section{Cabinets Ministériels}

The cabinet ministériel is a relatively rare phenomenon; its main examples in Europe are Belgium (whose system is now being dismantled), France and Italy. France is regarded as the classic example, since cabinets ministériels have operated there in a recognisably modern form for some 150 years. The Spanish country paper suggests that Spain may be moving towards this model. (It should be noted that, while Poland refers to its political advisors to ministers as cabinets, in practice most ministers are limited to three advisors, and they act more like political advisors in the sense described above, rather than as the cabinets described in this section.)

The cabinet differs from the political advisor systems described above in that it not only advises the minister but also provides political direction and management to the entire ministry. It issues instructions to the ministry in the minister's name, and its leading members usually have the right to sign documents on the minister's behalf, will often represent him/her at external events and will be regarded as speaking in his/her name, both within and outside the ministry.

Cabinets are usually composed of a mixture of civil servants and external appointees, and the latter, at least, are expected to be sympathetic to the minister's views. In France cabinets comprise between 20 and 30 staff for a minister and 10 to 20 for a subordinate minister. In Belgium until recently cabinets grew very large indeed, in some extreme cases as large as 100 members, until their size was curtailed by recent administrative reforms. Figures on the proportion of political appointees are difficult to find, but Olivier Schrameck (one-time director of the cabinet of French Prime Minister Jospin) estimates that roughly a quarter of French cabinet staff are outsiders appointed for political reasons.

Cabinet members will be personally selected by the minister; in the case of civil servants, this obviously undermines the traditional civil service hierarchy and is open to accusations of favouritism. It is difficult to write of the organisation and working methods of a cabinet since, as Olivier Schrameck has observed in his monograph on the subject, organisms founded on such a personal basis are nebulous rather than structured and require a sociological rather than a 
juridical treatment ${ }^{1}$. This is particularly true in France, where official restrictions on the size, staffing and financing of cabinets are frequently flouted with impunity.

The authority of the head of the cabinet ${ }^{2}$ runs across the ministry, with responsibility for all of its major political decisions - and, in France, its key administrative functions. Other cabinet members are usually responsible for specific subjects or policy areas. There are usually staff members with particular responsibility for parliamentary liaison, media relations, and the minister's constituency. Hierarchy within the cabinet is usually quite supple; personal considerations are more important. Schrameck's monograph repeatedly argues that cabinets should operate as teams, but acknowledges that many of then they do not and that competition between members is common. Many people serve several spells, at intervals and in positions of increasing seniority, in the cabinets of different ministers, which is a recognised means of professional advancement. However, a common criticism is that, being based on favouritism, this practice runs counter to the best practice of civil service advancement based on objective assessment.

The existence of the cabinet obviously diminishes significantly the role of the staff who lead the other departments of the ministry. As decision-making is pulled upwards into the cabinet, the rest of the ministry tends to be pushed into a technical role, with a strong emphasis on the execution of decisions reached above their heads (although it is not unknown for cabinet staff to involve themselves in the execution of more sensitive projects). Where there is a secretary-general, as in Belgium and Italy, his/her role has usually been more administrative and technical. This in itself can be turned into a significant role, particularly in budgetary and organisational matters, and the secretary-general can exercise quite a lot of influence under the heading of co-ordination. The absence of even this counterweight in France leaves the cabinet dominant. It is this extension of the role of political advisors from a mainly advisory role to what the Spanish study describes as a "central role in the design, implementation, monitoring and evaluation of public policies" which suggests that Spain is moving towards a French-style system.

The cabinet system also has an impact on inter-ministerial policy co-ordination, since a strong network usually develops between cabinets. Until recently in Belgium, cabinets were the main conduit for co-ordinating and negotiating important policy decisions between ministries. In France, they have taken on this role almost to the exclusion of political matters; inter-ministerial disagreements are settled not by meetings of ministers but of their cabinet staff. In Spain, as the study observes, the inter-ministerial network of political advisors exerts a powerful influence in determining whether the government adopts legislative projects or not. This is less true in Italy, but a regular meeting of the cabinet heads and the legal director of ministries is a key mechanism for managing the agenda of the weekly Italian Government meeting and for settling disagreements between ministers.

It is some indication of the attitude towards cabinets that Guy Carcassonne, himself the former chef de cabinet of Prime Minister Rocard, published a serious academic typology of cabinets, in which he characterised them as "mates, children, valets and lieutenants". [Note for translator: the French original is: "les copains, les enfants, les valets et les lieutenants ».]

In French cabinets ministeriels it is important to distinguish between the director of the cabinet, who has authority over the main political and administrative functions of the ministry, and the chef de cabinet, who enjoys a closer personal proximity to the minister, as he/she plays the role of gatekeeper, responsible for the organisation of the minister's schedule and professional life. Both figures are highly influential. 
The cabinet system has its merits. It provides the minister with the services of a group of (usually) highly capable people, many of whom are experts in their fields. It provides support for all facets of the minister's life (some civil service systems are certainly open to the accusation that they support adequately the minister's administrative and policy needs but not sufficiently his/her more political needs). In addition, the cabinet system is popular with ministers, who like to choose their own staff.

However, there are strong criticisms of the system, which may be summarised under two headings. The first criticism is based on principle: the cabinet system is in effect a closed circuit spoils system, based on favouritism rather than on objective merit, and it downgrades the civil service principle. (There is also an equal opportunities dimension: a recent study by Le Monde found that only 10 out of 700 cabinet members have what the newspaper termed "an immigrant background".). A common complaint in Belgium has been that civil servants, after serving in a cabinet, were often promoted outside the normal promotion procedures. The second set of objections centre on the system's inefficiencies: it makes ineffective use of the expertise in the rest of the ministry. Encourages short-term decision-making, leads to rivalry and "courtier" behaviour amongst cabinet staff, and encourages other staff in the ministry to engage in devious manoeuvring to influence the cabinet's decisions, leading to - in Schrameck's words "disequilibrium and abuse". One reason given by Prime Minister Balladur for his attempt in 1993 to restrict the size of cabinets in France - an attempt subverted by the system - was to stop them acting as "an obstacle" between ministers and their civil servants.

For these reasons, the cabinet system has long been subject to criticism. However, politicians are evidently reluctant to sacrifice such an obvious source of political patronage, even if the long-term effect is a lower quality of government and a debilitation of the system of public administration. In France, the institution has been subject to repeated criticism, notably in the 1993 report of the Blanc Commission, which concluded a forensic critique of its failings with a recommendation to restrict the overall number of cabinet staff to 100 (as opposed to 400 at the time and 700 today). However, all attempts at reform have foundered, and most writers on the subject seem to support Quermonne's pessimistic conclusion that the system - in France at least - can be changed only by abolition.

That was also the conclusion reached in Belgium, which in 1999 set out to abolish the cabinets at the federal level. The impetus for this decision came from a series of scandals and failures, including the dioxin and Dutroux affairs, which - according to one Senate report - led to the public service being seen as "excessively politicised, incompetent and unresponsive". These events contributed to the election of a government that gave high priority to radical public sector reform. Cabinets featured largely in this reform because their staffing had almost doubled since 1989 to an average of 30, and because - in the words of the Copernicus document, "cabinets tended to exert much wider control over the ministries' operations, and played a much more 'up front' role in policy-making. This was often perceived by civil servants working in the services as a sign of low esteem, and sometimes gave rise to friction between a minister and the services falling under his responsibility. It also led to a lack of continuity in policy-making, as ministerial cabinets would come and go with ministers after elections".

The Copernicus programme envisaged replacing in each ministry each cabinet with a small ministerial staff of personal collaborators selected by the minister; a strategy council to advise the minister on policy, comprising managers from the ministry's departments and external experts; and a "policy preparation cell" of civil servants and external experts recruited by the civil service recruitment organisation. Implementation has been slow, given Belgium's complex governmental structures and the controversial nature of the wider programme of Copernicus reforms, but the phasing out of cabinets is now well advanced. 
It is notable that the cabinet model has not been taken up in the democratisation of Eastern Europe (note the remark on Poland above). Nor has it been promoted much as an idea by western European consultants to eastern European governments, even by the European Commission, which in its own internal administration makes use of cabinets. Like the "spoils system" in the United States, in which all senior posts are filled by political appointees, the system is tolerated at home but recognised as not suitable for export.

\section{The Prime Minister's Political Advisors}

In most European countries, the prime minister is allowed a larger number of political appointees than other ministers. There appear to be two reasons for this: the prime minister must cover a far wider range of issues than other ministers, and therefore needs a wider range of advice; and the prime minister's functions are almost entirely political, as opposed to other ministers, whose duties often have a substantial regulatory or administrative component. A survey of OECD countries in 2004 showed that in 7 out of 15 countries, the majority of staff in the Prime Minister's Office were political advisors.

It is important to recognise that the prime minister is also supported by the Government Office (also known variously as the General Secretariat, Government Office, Government Secretariat, Chancellery, Cabinet Office, etc.), which in contrast is usually staffed by civil servants ${ }^{3}$. On the whole, the Government Office is responsible for policy co-ordination, work planning and monitoring, legal functions and communications, while the Prime Minister's Office is concerned more with political and policy advice, communications support and speech-writing. Therefore the division of responsibility between civil servants and political advisors at the centre of government is broadly similar to that in line ministries, and the need for a good working relationship between them is equally important.

On the whole, the same issues and dynamics appear to apply to political advisors working with the prime minister as apply in line ministries. The main differences are that they are often also responsible for the strategic planning of the government's work as a whole and that they deal mainly with ministers and their immediate advisers, rather than directly with functional departments in ministries. An additional function of the prime minister's advisors, found in many coalition governments, is the management of relations between the coalition parties, which may be institutionalised to a greater or lesser extent.

Generally, the influence of the prime minister's political advisors vis-à-vis the rest of the government will depend on the prime minister's own dominance or lack of it, due to a combination of institutional, personal and political factors. If the prime minister is dominant, his/her advisers can play an important role. This has certainly been true of recent governments in Spain and of the Blair Government in the United Kingdom, and is generally true of all countries with a cabinet system. However, prime ministerial dominance tends to magnify the role of the prime minister's political advisors, and not vice versa, as proved by the existence of dominant prime ministers without many political advisors. If the prime minister is weak, his/her advisors will struggle to establish their influence, as was seen under the short-lived Cresson Government in France.

It should be noted that in a number of countries (e.g. Denmark, the Netherlands and Poland) the entire mechanism serving the centre of government is referred to as the Prime Minister's Office. However, in such cases there is a clear functional division within that organisation between "Government Office" functions and Prime Ministerial support functions. 
As long as the role and influence of the prime minister's advisors are a reflection of their master's role and influence, this seems to be accepted as legitimate by the rest of the governmental system. Difficulties arise, however, when political advisors are given what amounts to a separate authority of their own towards ministers. This is a problem to some extent in France. It occurred for a while in Lithuania, where the prime minister's advisors were for a while given the legal authority, both individually and as a body, to review proposals put forward by ministers and to alter or reject them. The experiment was short-lived, and the resentment that it caused contributed to the demise after seven months of the government that introduced it.

The larger number of advisors to the prime minister leads in almost all countries to the appointment of a chief political advisor, who is usually a figure of considerable importance (although usually maintaining a relatively low public profile).

\section{Accountability, Ethics and What to Do When Things Go Wrong}

On the whole, the western European experience of political advisors has been a positive one. However, things will go wrong; occasionally political advisors or civil servants will break the rules. In the case of civil servants, there is a clear line of accountability; civil service legislation sets norms of behaviour, and there is a hierarchy to enforce the rules and sanctions for breaches of the rules. The position in relation to political advisors seems less satisfactory. This is an under-explored area, but while countries usually have some legal framework to govern the employment of political advisors, the framework for their accountability and ethical behaviour seems generally underdeveloped.

There are two key difficulties. The first is the absence of clear guidance to political advisors on behaviour and ethics. The second is the problem of accountability, in that the political advisor stands outside the ministry's chain of command, and his/her only responsibility is to the minister. If he/she does break the rules, the minister is unlikely to be severe with his/her favourite. Ministers are interested in getting things done to their political advantage, and do not always share civil servants' concern about propriety. Unless the behaviour causes serious public embarrassment, the political advisor is likely to be let off.

A rare study of this problem by King surveys practice in Australia, Canada, Ireland, New Zealand, and the United Kingdom and offers three useful lessons. The first is that while the United Kingdom has no civil service law (unlike the other countries surveyed and, indeed, unlike most countries in Europe), it has developed a strong ethical framework governing the activities of political advisors, in the form of a code of conduct (extracts of which are in the annex to this paper) and a model code of employment for political advisors. These codes provide a very clear framework and are useful models from which other countries can borrow. (The Denmark study below gives similar useful examples of a standard contract of employment, guidelines for the conduct of political advisors, and special guidelines for political advisors in their dealings with the media).

Second, leaving enforcement of the rules in the hands of the minister to whom the political advisor is responsible is ineffectual. This has proved to be the great weakness of the United Kingdom system, but it is also true in the other countries surveyed. There is a need for an independent procedure for handling and investigating breaches and imposing sanctions. Third, as King writes, "legal regulation on its own is not enough. The promotion of virtue is as important as the control of vice. Codes of conduct need to be developed in dialogue with civil servants, and ethical behaviour needs to be promoted in a variety of different ways, through induction training, seminars and human resources management". (There are parallels in the recommendations of the Danish Commission for better training - see the Danish study). 


\section{Conclusion and Lessons}

It is extremely difficult to assess the effectiveness of political advisors. Impact on policy is always difficult to discern. There are occasions on which an advisor can point to a particular decision and claim credit for a decisive influence, but these incidents are rare. More often, when the political advisor thinks he/she has achieved something, he/she may find that he/she was pushing on a door that was already opening, or that his/her advice simply coincided with advice coming from elsewhere. Another possible measure of effectiveness is ministerial satisfaction. This is difficult to gauge, not least because a minister is unlikely to admit publicly that he has made a bad appointment. Perhaps the best indicator if success is survival. A high proportion of innovations in the machinery of government do not last long. Political advisors, as a species, are a relatively recent innovation in most countries and have usually endured where they have been tried.

What lessons can be derived from this synopsis? They are as follows:

- $\quad$ The functions of political advisors should be clearly specified, preferably in legislation. Ideally this should be reinforced by a code of conduct for political advisors. Observance of the regulation and code should be a contractual obligation of political advisors.

- The respective responsibilities of political advisors and civil servants should be defined with clarity. Where the boundary is drawn between them is a secondary issue; the point of primary importance is that there should be a boundary that is clearly marked, generally understood and respected.

- However, the demarcation of functions between the two groups should be a line that helps them to understand their respective functions and not a barrier preventing them from working together to achieve their minister's objectives. Simple day-to-day working arrangements, such as regular meetings, are needed to manage the working relationship between political advisors and senior civil servants in the ministry, in particular to share information and to agree the allocation of work between them.

- Political advisors should act with common sense and circumspection. They should not abuse their privileged access to the minister, to his/her meetings or to information.

- $\quad$ Civil servants should work with political advisors and support them in carrying out their distinct and separate role.

- $\quad$ An ethical framework is needed to supplement the legal framework governing political advisors, parallel to the framework in place for civil servants. It could usefully include a code of conduct. Its operation should be reinforced by training and human resources management.

- $\quad$ An independent mechanism to investigate and punish breaches of the rules governing political advisors' behaviour is needed, parallel to the mechanism that should exist for the investigation and punishment of breaches by civil servants. 


\section{References}

Barbasiewicz, A. and M. Kulesza (1999), Administration in Support of Government: the Functions and Organisation of Political Cabinets in Poland and in Some Other European Countries, Chancellery of the Prime Minister, Government of Poland, Warsaw.

Ben-Gera, M. (2003), Co-ordination at the Centre of Government: the Functions and Organisation of the Government Office - A Comparative Analysis of OECD, CEEC and Balkan Countries, Sigma, Paris.

Ben-Gera, M and S. James (2004), A Comparative Analysis of Government Offices in OECD Countries, GOV/PCG/MPM/RD/(2004)1, OECD, Paris.

Bigaut, C. (1997), Les Cabinets ministérie/s, LGDJ, Paris.

Blanc, C. (1993), Pour un État stratège, garant de l'intérêt général; report for the preparation of the $11^{\text {th }}$ National Plan, La Documentation française, Paris.

Braun, G. (2001), La réforme de l'Etat à l'étranger, Rapport du Sénat - Commission des Finances, no. 348, Sénat de la Belgique, Brussels.

Cabinet Office (2005), Model Contract for Special Advisers, UK Cabinet Office, London. See: http://www.cabinetoffice.gov.uk/propriety and ethics/publications/doc/model contract special a dvisers.doc

Carcassonne, G. (1986), «Typologie des cabinets», in Pouvoirs, Vol. 36.

Destexhe, A., A. Eraly and E. Gillet (2003), Démocratie ou particratie? 120 propositions pour refonder le système belge, Editions Labor, Liège.

Dooney, S. and J. O'Toole (1998), Irish Government Today, Gill and Macmillan, Dublin.

James, S. (1998), British Cabinet Government, $2^{\text {nd }}$ edition, Routledge, London.

Kessous, M. (2003), «Minorités peu représentés sous les dorures de la République» in Le Monde, 24 November 2003, Paris.

King, S. (2003), Regulating the Behaviour of Ministers, Special Advisers and Civil Servants, University College London, London.

Office of the Prime Minister of Kosovo, OSCE, Public Administration International and Sigma (2006), From Politics to Policy: Building Effective Teams of Political Advisers and Senior Civil Servants, OSCE, Pristina.

Pelgrims, C. (2005), "Personal Advisors of Ministers: more than personal loyal agents?"; Paper presented at the $13^{\text {th }}$ NISPACee Annual Conference, Moscow, 19-21 May 2005.

Quermonne, J-L. (1994), «La 'mise en examen' des cabinet ministériels», in Pouvoirs, vol. 68.

Schrameck, O. (1995), Les Cabinets ministériels, Dalloz, Paris.

Service Public Fédéral - Personnel et Organisation (2004), Copernicus: au centre de l'avenir, SPF, Brussels. 
Sigma (1996), Civil Service Legislation Contents Checklist, Sigma Paper No. 5, Sigma-OECD, Paris.

Sigma (1998), Management Challenges at the Centre of Government: Coalition Situations and Government Transitions, Sigma Paper No. 22, Sigma-OECD, Paris.

Sigma (1999), European Principles for Public Administration, Sigma Paper No. 27, Sigma-OECD, Paris. 


\title{
II - COUNTRY CHAPTERS
}

\author{
DENMARK
}

\author{
Thomas Broeng Jørgensen \\ Rikke Ginnerup \\ Heads of Section, Ministry of Finance \\ Denmark $^{4}$
}

\section{Country Background}

\subsection{The Danish General Administrative and Political Context}

The administration in Denmark consists of 19 ministries (including the Prime Minister's Office), 60 agencies and a wide variety of institutions, including state-owned enterprises and other bodies with various connections to the state.

The Danish Constitution does not provide detailed regulations on the structure, organisation and procedures of central government. However, two constitutional rules are important in order to understand the Danish ministerial system. First of all, the Prime Minister is the sovereign responsible for appointing and dismissing ministers and for making decisions on ministerial portfolios. Secondly, the legal and normative principle of ministerial responsibility plays a fundamental role in the system.

The minister is personally accountable for any activity within the ministry relating to parliament while at the same time being responsible for both political and administrative affairs in the departments and agencies of the ministry. The minister therefore has a high degree of autonomy. In the Danish system, as opposed to a cabinet office system, neither the Prime Minister nor the cabinet collectively can give formal instructions to a minister on a specific issue. However, since the Prime Minister is responsible for appointing and dismissing ministers and for undertaking ministerial reshuffles, the minister ultimately depends on the Prime Minister's will and sovereignty.

Besides these fundamental traits of the Danish system, the civil service can be seen as largely corresponding to the Weberian ideal type of bureaucracy. The civil service is thus a merit bureaucracy and a career system in which senior civil servants are mainly recruited from within the ministry and are politically neutral.

As for the political context, an important aspect of Danish government is that political groups are typically based on minority coalition governments. Thus the co-ordination process, which takes place mainly in two committees (the Economics Committee and the Co-ordination Committee), and interministerial conflict-solving are very important tools for ensuring "integrated" policies.

This paper expresses the personal views of the two authors and not necessarily those of the Danish Ministry of Finance or the Danish Government. 


\subsection{The Development of Politico-Strategic Counselling in Denmark}

Since the middle of the 20th century, many countries have focused increasingly on the need for civil servants who have supplemented their legal and budgetary competencies with more politico-strategic capabilities. Denmark is no different from any other country in this regard and, particularly in recent years, integrated policy advice and politico-tactical advice have taken on added significance.

The pattern of this trend has been to replace legally trained civil servants with economists having new skills and eventually also with political scientists possessing a keen eye for the political context and capable of manoeuvring in the face of various political obstacles. In Denmark developments since the first Constitution of 1848/1849 until today can be divided into three periods. From 1848 to 1901 there was no clear separation between civil servants and politicians. A civil servant could thus switch from being a permanent secretary to become a minister and often had several "side jobs" besides that of a civil servant. From 1901 to 1945 civil servants closely resembled the type described above, with strong legal and budgetary competencies. During this period the civil servant was a day-to-day administrator who left politics to the politicians. From 1945 until today we have seen a gradual return to the civil servant who acts at the same time as a political advisor.

The main conclusion to be drawn from this quick account is that a civil service that provides political advice is by no means a new phenomenon in Denmark. Therefore the distinction that is often established between professional policy advice and politico-tactical advice is not always tenable in today's Denmark.

In the following section, the role and responsibilities of the permanent civil service and of politically appointed civil servants (special advisors) will be further examined.

\subsection{The Role and Responsibilities of the Permanent Civil Service}

Ministerial advice and assistance in Denmark are mainly based on a permanent and politically neutral civil service. Consequently, recruitment and appointment to positions in the civil service are decided on the basis of the principle of selection by merit and not of political affiliation.

The permanent civil service is both willing and able to provide comprehensive, professional politico-tactical advice. When giving this advice, however, the civil service has to pay special attention to the requirements of professional standards, party political neutrality, legality and the obligation to speak the truth.

Professionalism in general dictates the adherence to recognized standards within a given field, e.g. economic standards for conducting budget analysis. The norm of party political neutrality implies that the permanent civil service should abstain from giving advice during election campaigns and from contributing to campaign materials, drafting speeches for party congresses, etc.

Permanent secretaries (departementschefer) have played a key role in the post-war trend towards more comprehensive politico-tactical advice from the permanent civil service. Still today permanent secretaries by far account for the most important political advice provided to the minister.

In addition to the advice provided by permanent secretaries, political advice is also given through various functions in the ministry. Private secretaries (ministersekretær) are usually involved in providing some form of political advice, although practical services to the minister - such as assisting in contacts with parliament, co-ordinating briefings of the minister, assisting in press 
relations, controlling and updating the minister's schedule - remain their most important functions.

Other civil servants, such as deputy permanent secretaries and heads of divisions, also provide important political advice. Even heads of sections give policy advice in written notes, etc. However, the extent to which section heads have direct access to the minister to provide face-to-face advice varies considerably.

Finally, some political advice is fed to ministries through political party secretariats. This almost always takes place through the minister, who then passes an idea down to the ministry, where extensive treatment of the strategy or issue will subsequently be carried out. This phenomenon is not widely observed in Denmark as the government has access to a very resourceful pool of advisory capacity in the ministries themselves. However, the coalition does not have access to ministries and uses political party secretariats to a much greater degree than the government does.

In this regard it is important to stress that ordinary members of parliament, whether or not they are partisans of the ruling government's party (or parties in the case of a coalition government), cannot ask ministries to carry out an analysis of a specific issue without going through the formal channels, usually through the minister.

The table below summarises who is involved in presenting ministerial business face-to-face to the minister. On the whole, as reflected in the table, the same tendency applies to all sorts of contacts with ministers, including written politico-tactical advice. Interaction with the minister is concentrated at the senior civil service level, and involvement at lower levels varies considerably from one ministry to another.

Table 1. Who is in involved in presenting ministerial business face-to-face to the minister?

N=18 ministries (The Prime Minister's Office is not included.)

\begin{tabular}{llllllll}
\hline & $\begin{array}{l}\text { Every } \\
\text { time }\end{array}$ & Often & Sometimes & Rarely & Never & Irrelevant & Total \\
\hline $\begin{array}{l}\text { Permanent } \\
\text { secretary }\end{array}$ & 12 & 4 & 1 & 0 & 0 & 1 & 18 \\
$\begin{array}{l}\text { Deputy } \\
\text { permanent }\end{array}$ & 1 & 11 & 4 & 0 & 0 & 2 & 18 \\
$\begin{array}{l}\text { secretary } \\
\text { Head of division }\end{array}$ & 3 & 9 & 4 & 1 & 0 & 1 & 18 \\
Head of section & 1 & 6 & 8 & 0 & 2 & 1 & 18 \\
Director of agency & 2 & 2 & 7 & 4 & 1 & 2 & 18 \\
\hline
\end{tabular}

There is usually a very high level of satisfaction among ministers concerning the advice and assistance offered by the permanent civil service with regard to both policy advice and politico-strategic advice. Ministers are less satisfied, however, with the assistance provided in speech-drafting. Furthermore, the fact that ministers tend to recruit special advisors with media expertise suggests that there is room for improvement of the capability of the permanent civil service to handle press relations.

In recent years several ministries have reorganised departmental structures (e.g. building larger political secretariats close to the minister) in order to strengthen policy functions and the capabilities of permanent civil servants to provide ministerial advice (cf. Box 1 below). 


\section{Box 1. The organisation of ministries and ministerial advice}

A typical ministry is headed by a minister with a small secretariat (staffed by two private secretaries with academic backgrounds and a politically appointed advisor), followed by a permanent secretary with a small secretariat (staffed by a private secretary with an academic background), further followed by divisions and smaller sections, etc. In recent years, several ministries have reorganised the departmental structure and a major driving force has been the intention to strengthen policy functions and capacities for delivering rapid and sound ministerial advice.

There is a trend in ministries to build larger political secretariats around the minister. The staff in secretariats is often talented and fairly young bureaucrats with special capabilities in developing new policy, co-ordinating political processes and reform programmes, drafting ministerial speeches, etc. As mentioned above, ministers are less satisfied with the permanent civil service's assistance with speech-drafting. Political secretariats are also seen as a solution for improving these skills within the permanent civil service.

A major challenge is to ensure close co-operation and co-ordination between the line organisation and political secretariats. The distinguishing and positive aspect of the permanent civil service in general is its ability to provide both policy advice and politico-strategic advice at all levels of the organisation.

\subsection{Special Advisors' Roles and Responsibilities}

The use of politically appointed civil servants (special advisors) has historically been limited in Denmark compared to other western democracies. In Norway, Sweden and the United Kingdom, the use of politically appointed state secretaries and junior ministers as well as political advisors can be observed. Politically appointed civil servants are both numerous and tightly integrated into the conduct of government.

In Denmark, however, only one politically appointed minister is in charge of managing the ministry, including the agencies of the ministry, and only one special advisor is appointed per minister ${ }^{5}$. It is important to emphasise that the special advisors' roles and responsibilities cannot be compared to those of state secretaries and junior ministers in many other OECD countries.

Special advisors are mainly employed to deal with press-related functions, e.g. contacts with journalists, press releases, and contributing to interviews. Only a very few special advisors spend the majority of their time giving politico-tactical advice to the minister, thus fulfilling the role of a "spin doctor" as often portrayed in the media.

There are exceptions to this pattern, however. In matters of importance concerning the Prime Minister's Office, for instance, the special advisor is very close to the minister and to the permanent secretary and participates in management meetings with the ministry. At the same time, the special advisor is able to provide the press with background information on the substance in current matters, political insights and objectives, etc.

There are but a few special advisors in Danish ministries. In 2005, only 14 of 20 ministers employed a special advisor, and no minister has ever had more than one special advisor. Thus six ministers have chosen to rely solely on the permanent civil service for policy advice,

Except for the Ministry of Foreign Affairs, where two ministers are in charge (general foreign affairs and development issues). 
politico-tactical advice and press relations. It seems to be the preference of the minister rather than the specific tasks of the ministry that determines whether or not a special advisor is employed.

Of the 14 special advisors, eight have degrees in journalism and/or work experience in the Danish media. The remaining advisors are typically academics with in-depth experience of journalism and/or employment in political party secretariats. Hardly any of the special advisors have had the experience of previous employment in the civil service.

The majority of special advisors in Denmark thus have degrees in journalism and/or work experience in the media. This can be seen as reflecting the ever increasing importance of the media in society and politics.

During the 1980s and 1990s there was a small increase in the use of special advisors who were politically appointed and separate from the civil service. This trend led to White Paper 1354/1998, which dealt with the relationship between the permanent civil service and politically appointed special advisors.

The above white paper defined the special advisors' roles and responsibilities for the first time. The defining character of special advisors is that their employment is tied to the minister's term in office and that they are employed in the minister's private secretariat and cannot have executive powers over civil servants employed outside the private secretariat.

Another white paper was published in June 2004 (White Paper 1443/2004), mainly as a result of a public debate on two issues. The first debate was on the limits to permanent civil servants' involvement in matters of party political significance. The second debate concerned the rules for civil servants employed as special advisors.

White Paper 1443/2004 resulted in a number of recommendations regarding rules for civil servants and the use of special advisors. Although the wording is clear and unequivocal, the rules can best be described as "soft" guidelines, in contrast to "hard" legislation. The most important guidelines are the following:

1. First of all, special advisors are subject to the same requirements of professional standards, obligation to speak the truth and legality as permanent civil servants. Only the requirement of party political neutrality differs. Unlike civil servants, special advisors should be allowed to assist their ministers in relation to parliamentary elections. However, special advisors should be given notice of discharge during the election campaign and should therefore not be allowed to use the facilities of the ministries (including network access, etc.).

2. The white paper recommends that powers and functions should be well defined so that the existence of special advisors will not create uncertainty about managerial responsibilities in ministries. Special advisors should therefore not be given power to instruct permanent civil servants outside the minister's private secretariat. Also, it should be clear that special advisors, like permanent civil servants, report to the permanent secretary who has been delegated management responsibility by the minister.

3. The white paper recommends that not more than two or three special advisors should be employed per ministry. The committee responsible for preparing the white paper ${ }^{6}$ felt that it would be sensible to make room for the various functions of special advisors (politico-strategic advice, communication, etc.) while at the same time containing their influence by restricting their

Expert Committee on Civil Service Advice and Assistance to the Government and its Ministers. 
numbers to two or three. However, the Prime Minister had announced in 2001 that each minister should employ only one special advisor, and this recommendation of a single advisor has not been changed since the publication of the white paper.

4. The white paper states that openness and transparency in relation to the employment of special advisors is of great importance in order to avoid public distrust. To promote more openness about the use of special advisors, information on their background is published on the Web site of the Prime Minister's Office.

5. Last of all, the white paper recommends various ways of handling press relations (cf. Box 2 below).

\section{Box 2. The increasing need for special advisors seen in the light of the changed media focus}

It is no coincidence that political communication is now taught in all major political science programmes all over the world. In this way the media's enormous role in society has also been reflected in the political world, where the use of special advisors in Denmark can be seen as an answer to the need to deal with the media in a more efficient way.

There have been some cases in Denmark where a journalist, after giving negative or unfair treatment to a minister, was virtually frozen from professional relations with the ministry in question. White Paper $1443 / 2004$ includes a whole section on how to handle the media in an appropriate way.

First, as a general rule all of the civil servant's normal administrative principles, such as objectivity and non-discrimination apply to relations between the media and special advisors. In other words, special advisors are obliged to speak the truth when talking to journalists and cannot decide which journalists they will speak to. White Paper 1443/2004 clearly states in this regard that the press should as far as possible be treated equally, even if a journalist has previously been unfair to the minister.

Second, the use of "news exclusives" can be used if they are based on valid grounds in the particular case. A valid ground for using news exclusives could be that a government initiative would get more attention and a more comprehensive consideration if presented in the media. At the same time, however, the principle of non-discrimination implies, among other things, that a ministry that has given a news exclusive to one journalist must provide the same information to other journalists if they request it. However, some stories do not qualify as being suitable for news exclusives. This could, for example, be the case of political initiatives that are of such great public importance that whether or not to publish the news would not be an option.

Third, the slicing of a news exclusive (timing of several parts of the story over a period of days) can be allowed. Information offered in this way must not be misleading, and ministries should inform the journalist that the information is only part of a larger initiative and should be seen in the relevant context.

Fourth, ministries cannot decide which journalists a given medium should send to press meetings, press briefings, interviews, etc. However, there may be valid grounds for inviting certain journalists, for example due to their knowledge within a specific subject area. White Paper 1443/2004 underlines that the minister has broad discretionary power in terms of deciding which interviews he/she wants to participate in.

\subsection{Track Record of Implementation in Practice}

The Danish Government in June 2004 issued a press statement indicating that by and large White Paper 1443/2004 is representative of the government's position and that ministries must adhere to the guidelines of the white paper.

As a follow-up to White Paper 1443/2004, a standard job contract for special advisors was drafted - based on the guidelines of the white paper - and is now used as a basis for the employment of new special advisors in ministries (cf. Box 3 below). 


\section{Box 3. The standard job contract for special advisors}

The standard job contract for special advisors has the following provisions:

Place and sphere of work;

Guidelines indicated in White Paper 1443/2004;

Public information on the employment of the special advisor;

Salary and terms of employment, pension, vacation and working hours;

Guidelines for termination of employment;

Other provisions of employment (free phone, newspaper, Internet access, etc.);

The contract specifies that a special advisor is subject to the Danish Criminal Code and the Danish Public Administration Act. Furthermore, a special advisor cannot issue instructions to civil servants in the line organisation. The contract also specifies that information will be published on the Web site of the Prime Minister's Office regarding the individual special advisor's function, work place, and background. And finally, the contract specifies that a special advisor is given notice of discharge when a new election is announced.

Prior to the publication of White Paper 1443/2004, there had been some ambiguity as to whether special advisors were subject to the managerial responsibility of permanent secretaries and concerning the special advisors' power to give instructions to permanent civil servants.

The white paper made it clear that the permanent secretary has managerial responsibility for special advisors and that only permanent civil servants can give instructions in the civil service. This principle governs the relationship between special advisors and civil servants.

As another follow-up to the white paper, the government decided that all new special advisors should be instructed in the organisation, modus vivendi and procedures of the ministerial system so that they could operate more effectively in the system. The following section will focus on the training programme that is mandatory for new special advisors.

\subsection{Existing Training Programmes}

Special advisors usually have different backgrounds from those of traditional civil servants. Most of them come from a job in the media and have neither theoretical nor practical knowledge of public administration. This means that some training is required so that special advisors are able to quickly adapt themselves to the work culture of the ministry in question and at the same time acquire knowledge of the general rules, such as those provided by the Public Administration Act.

The Danish Government has for this purpose introduced a specific training programme for special advisors (cf. Box 4 below). 


\section{Box 4. Training programme for special advisors in Denmark}

The Ministry of Finance and the Ministry of Justice have set up, following the publication of White Paper 1443/2004, a training programme for special advisors. The agenda of this programme consists of the following items:

Government's policy regarding special advisors

Basic history and organisation of the central administration

Ministerial system and services provided to the minister

Development of the civil service in Denmark

Appearance and history of special advisors in Denmark

General rules about administration and reading of the Public Administration Act

Guidelines for special advisors' communication to the media

Rules regarding access to archives

Rules regarding the minister's responsibility

\subsection{Comments on Likely Future Trends and Need for Reform}

The Danish Government has agreed, with its publication of White Paper 1443/2004, that the number of special advisors per minister should be limited in order to avoid a gap between the politico-tactical advice of special advisors and the professional policy advice of the permanent civil service. This limitation ensures two functions. First of all, it provides a clear demarcation and secondly, it constitutes an insurance that politically appointed special advisors - due to their small number - will be able to work in co-ordination with the civil service.

The government has maintained, even after publication of the white paper's recommendation to employ a maximum of two or three special advisors, that the number of special advisors should in fact be limited to only one per minister, with the primary task of giving advice on media relations.

This decision consolidates the Danish system of a politically neutral civil service that gives comprehensive, professional politico-tactical advice. The decision provides an important clue as to the current government's vision for the role of political advisors. Politically appointed civil servants will thereby provide a useful supplement to the civil service through their special competencies in handling the minister's relations with the press.

A precondition for a successful integration of special advisors into ministries, however, is that the recommendations of White Paper 1443/2004 will be followed so that a clear distinction remains between the functions of politically appointed staff and traditional civil servants. Furthermore, co-operation between the two groups must be based on mutual respect, a real understanding of each other's functions, and continual close contacts.

The Danish system is unique, in a comparative perspective, because there is only one minister in charge of ministerial affairs. The advantage of this system is a clear political responsibility. The question, however, is whether the increasing workload and complexity of ministerial affairs will present a challenge to the Danish system of one minister per ministry.

If the Danish system were to change in this regard, it would probably move towards the British system of junior ministers rather than towards the Swedish system of state secretaries. In the British system junior ministers pursue a career in parliament, which is more in line with the Danish tradition of separating the functions of the permanent civil service from the functions of politically appointed representatives. 
Another question is whether permanent secretaries can, in the light of the ever increasing number of issues, preserve the time needed for required politico-strategic insight. Permanent secretaries currently fulfil many roles. They are at the same time the key political advisor to the minister and the person responsible for the ministry's administration, implementation of policies and development as an organisation. These two roles entail a large number of functions to perform, and the question arises as to whether a division of this workload might be relevant in some ministries. 


\section{References}

Bogason, Peter (1997), Forvaltning og Stat, Systime, Århus.

Christensen, Jørgen Grønnegård (1980), Centraladministrationen: Organisation og politisk placering, Jurist og økonomiforbundets forlag, Copenhagen.

Christensen, Jørgen Grønnegård and Marius Ibsen (1991), Bureaukrati og bureaukrater, Systime, Herning.

Christensen, Jørgen Grønnegård (1999), "Det tidløse ministerstyre”, in Andersen, Jørgen Goul et al. (eds.), Den demokratiske udfordring, Hans Reitzels forlag, Copenhagen.

Cook, Timothy E. (1998), Governing with the News: The News Media as a Political Institution, University of Chicago Press, Chicago.

Knudsen, Tim (ed.) (2000), Regering og embedsmænd: Om magt og demokrati $i$ staten, Systime, Århus.

Lund, Anker Brink (2002), Den redigerede magt - nyhedsinstitutionens politiske indflydelse, Aarhus Universitetsforlag, Århus.

Pedersen, Ove K., et al. (2000), Politisk Journalistik, Center for Journalistik og Efteruddannelse, Århus.

Peters, Guy and Jon Pierre (2004), Politicization of the Civil Service in Comparative Perspective: The Quest for Control, Routledge, London.

White Paper 1354/1998 (1998), Forholdet mellem minister og embedsmænd, Betænkning fra udvalget om forholdet mellem minister og embedsmænd, Schultz, Copenhagen.

White Paper 1443/2004 (2004), Civil Service Advice and Assistance, Report of the Expert Committee on Civil Service Advice and Assistance to the Government and its Ministers, Schultz, Copenhagen. 


\section{POLAND \\ Jacek Czaputowicz \\ Deputy Head of Civil Service, Office of the Civil Service Lecturer at Collegium Civitas, Warsaw \\ Poland}

\section{Political Tradition}

The political tradition of Poland's civil service system and its separation from the political sphere can be traced back to the beginnings of the independent Polish state created in 1918 and hence to the Second Republic of Poland in the interwar period.

The first comprehensive regulations concerning the formal structure of the civil service were drafted as the Act on the State Civil Service System of 17 February $1922 .^{7}$ That Act, with many subsequent amendments, remained in force until 31 December 1974, when it was replaced, as in other communist countries, by the Labour Code. This change weakened the position of civil servants vis-à-vis their superiors in that it made it easier to exert political pressure on them. Adopted in 1982, the Law on Employees of State Offices was meant to increase respect for civil servants and for the public administration. ${ }^{8}$ However, generally in the period of the Polish People's Republic political loyalty to the Communist Party was the decisive factor. The nomenklatura system meant that the staffing of higher positions in the public administration was the result of political decisions, i.e. it was not based on genuine merit. The political and civil service spheres were intertwined. Public administration based on a clear separation of the political and civil service spheres did not begin to function until after 1989.

\section{Today's Situation}

The division between the political and civil service spheres is reflected in the Law of 1996 on the Organisation and Rules of Procedure of the Council of Ministers and on the Sphere of Competence of Ministers. ${ }^{9}$ The point of departure in this law was the conviction that for an efficient functioning of public administration the separation of the political administration function (administration for governance) and executive administration was necessary. It was also understood that the mode of employment for the people performing each of these functions had to be distinct. ${ }^{10}$

See A. Górski, "The Civil Service Act of 18 December 1998 in the Light of Civil Service Acts of 1918-1922", in The Polish Yearbook of the Civil Service 2002. On the political neutrality of the civil service systems after 1918 and after 1989 see A. Górski, "Civil servans czy politicus servans - w okresie międzywojennym i obecnie" [Civil servants or political servants - in the interwar period and now], in Służba Cywilna no. 3/2002, pp. 71-97.

Ustawa o pracownikach urzędów państwowych [Law on Employees of State Offices] of 16 September 1982, Dz. U. Z 1982 r., no. 31, poz. 214.

Ustawa z dnia 8 sierpnia 1996 r. o organizacji i trybie pracy Rady Ministrów oraz o zakresie działania ministrów [Law on the Organisation and Rules of Procedure of the Council of Ministers and on the Sphere of Competence of Ministers] of 8 August 1996], Dz. U. z 1999 r., no. 82, poz. 929. 
The Law provides the legal basis for the functioning of political cabinets in the Polish administration. According to article 39 , point 3 , the political cabinet of a minister may exist in every ministry.

The political element consists of the minister and his/her deputies, who may replace the minister in the function of governing a branch of public administration and may represent the minister in parliament. The political element also consists of political advisors, who take part in programme work and help the minister in his/her contacts with the electorate, parliamentary clubs, social organisations, trade unions, the mass media, and foreign partners.

According to the Polish Constitution, ministers "shall direct a particular branch of government administration or perform tasks allocated to them by the Prime Minister". ${ }^{11}$ This formulation places the accent on the political responsibility of the minister for the state of affairs in a defined field and not on the execution of administrative tasks. A minister should therefore be in control of the conceptual, budgetary, legislative and personal activities of the ministry. In the performance of his/her tasks the minister is supported by deputies and a political cabinet, as well as by the corps of civil servants. ${ }^{12}$ The civil service sphere is governed by the Civil Service Law of 18 December 1998. The Law upholds the constitutional principle that stipulates that the civil service law guarantees the professional, reliable, impartial and politically neutral performance of the state's tasks. ${ }^{13}$ The civil service is to carry out the commands of the government of the day, but also needs to serve the interests of the state, be loyal to the Constitution, and comport itself according to the rules of democratic society. ${ }^{14}$

The systems for recruiting members of political cabinets - political advisors and civil servants differ. The former are recruited for the period during which their political superiors perform their functions (minister, deputy minister, voivode), while the latter are recruited in open competition for an open-ended period of time.

The Council of Ministers in 2001 determined that the maximum number of political advisors in the political cabinet of a deputy prime minister would be six, of a minister - four, of the Chief of the Prime Minister's Chancellery - two, and of the secretary of state - one. Undersecretaries of state lost the right to have a political advisor. ${ }^{15}$ The reasons for this decision seem to be found in public opinion's bad perception of political advisors, doubts concerning their role, and the will to cut costs in public administration.

see D. Bach-Golecka, "The Civil Service and Political Authority in Government Administration", in The Polish Yearbook of Civil Service 2005.

Article 149, point 1 of the Constitution of the Republic of Poland of 2 April 1997:

http://www.seim.gov.pl/prawo/konst/angielski/kon1.htm.

See M. Kulesza and A. Barbasiewicz, "Functions of Political Cabinets", op. cit., pp. 42-43.

The Law on the Civil Service of 18 December 1998: http://www.usc.gov.pl/gallery/65/655.doc. For a description of the problems faced by the Polish civil service, see J. Czaputowicz, "The Civil Service in Poland - between Politicization and Professionalization", in The Polish Yearbook of the Civil Service 2005, pp. 23-45.

The first Law on the Civil Service came into force on 5 July 1996. However, the qualification procedure to become a nominated civil servant was conducted dishonestly, and therefore after the election of 1997 the decision was taken to initiate a new law. See K. Burnetko, "Służba Cywilna w III RP: punkty krytyczne" [The Civil Service in the III Republic of Poland: critical points], in Raport Fundacji im. Stefana Batorego, 2003 r., s. 21-31; Z. Derdziuk et al., Raport z przeprowadzonej analizy i oceny tworzenia służby cywilnej (sierpień-wrzesień 1997), [Report of the analysis conducted and an evaluation of the establishment of the civil service (August 1996-September 1997)],Warsaw, February 1998. 
Soon further reduction in the number of political advisors took place. The programme to reduce public spending from 8 October 2003 eliminated as from 1 January 2004 the posts of political assistant to the secretary of state and reduced the number of posts in political cabinets of ministers to three and of deputy prime ministers to five. Consequently, the total number of posts in political cabinets decreased from 82 to 46, which brought savings of about 1.8 million PLZ per year (about 464000 EUR). ${ }^{16}$ In practice, the decision of the Council of Ministers concerning the limitation of the number of people employed in political cabinets can be easily changed. Since the parliamentary elections of 25 September 2005, the number of employees in political cabinets has been increasing. This number depends in practice on the budgetary situation of a ministry.

Article 47 of the Law on Employees of State Offices states that persons employed in political cabinets of the Prime Minister and ministers, as well as advisors of other persons occupying leading state posts, are employed on the basis of contracts of limited duration for the period of time a person occupying a state post performs his/her relevant functions. ${ }^{17}$

The Order of the Council of Ministers of 28 March 2000 regulates the rules for the remuneration of employees in political cabinets and advisors of persons occupying leading state posts. Remuneration of a member of a political cabinet consists of basic salary, service allowances for team management, and increases based on long-term employment (seniority). The rules for granting special bonuses, seniority pay, jubilee premiums, and other rewards are the same as for employees who are not civil service corps members and are employed in the offices of governmental administration. ${ }^{18}$

\section{The Tasks and Organisation of Political Cabinets}

The main tasks of a political cabinet are to give political advice and to perform assigned duties.

The political cabinet of the Prime Minister is, according to the law, an advisory-analytical team. Its tasks consist of giving political advice and organising the Prime Minister's contacts. The undersecretary of state is usually the head of a cabinet. The number of advisors is decided by

Program uporządkowania i ograniczenia wydatków publicznych [Programme for restructuring and limiting public expenditure], Rada Ministrów, Warsaw, October 2003. In May 2005 the report on the full realisation of that task was published. See Raport z realizacji "Programu uporządkowania i ograniczenia wydatków publicznych" [Report on the realisation of the "Programme for restructuring and limiting public expenditure"] Rada Ministrów, Warsaw, May 2005.

Ustawa z dn. 16 września 1982 r. o pracownikach urzędów państwowych, op. cit. The Law on Employees of State Offices is the only law that establishes rules for the engagement of political appointees [article 47(1)]. Article 47 was added on the basis of article 88, point 5, of the Civil Service Act of 5 July 1996 and came into force on 1 January 1997. The text of article 47(1) is as follows: "The employment: 1) of an employee in the political cabinet of the Prime Minister, Deputy PM, minister and any other member of the Ministers' Council 2) of advisors of persons who act as executives in state positions other than those enumerated in point 1), takes place on the basis of the contract concluded for the time of performing the functions by the person occupying the state post. The cancellation of the contract can be made with two week's notice."

Rozporządzenie Rady Ministrów z dnia 28 marca 2000 r. w sprawie zasad wynagradzania i innych świadczeń przysługujących pracownikom urzędów państwowych zatrudnionym w gabinetach politycznych oraz doradcom lub pełniącym funkcje doradców osób zajmujących kierownicze stanowiska państwowe [Council of Minister's Regulation of 28 March 2000 on remuneration and other benefits for employees of state offices employed in political cabinets and for advisors of persons who act as executives in state positions], Dz.U. z 2000 r., no. 24, poz. 296. 
the Head of the Prime Minister's Chancellery and not by law. The Secretariat of the Prime Minister provides organisational, office, and chancellery services to the political cabinet. ${ }^{19}$

The cabinet of a minister focuses as a rule on the most important tasks of a ministry. It develops political and content-related strategy, and gathers and selects information necessary for proper decision-making. Its activity is directed "within" the ministry, and its advisory role cannot by combined with decision-making.

The competencies of political cabinets are enumerated in the internal regulations of each ministry, although the scope of regulations differs. Currently only the statutes of internal organisation within some ministries give details on the tasks and organisation of political cabinets. The regulations differ from ministry to ministry. Some ministries regulate it and some do not.

For example, among the concrete tasks of a political cabinet in the Ministry for the Environment are: (1) initiating activities of a political and substantive character; (2) working out a strategy and directives in accordance with government policy and verifying in this respect the work of organisational units; (3) analyses of political, economic and social events in the light of government policy; (4) co-operating with political parties, parliamentary clubs, government and self-government administrations, non-governmental organisations, and the political cabinets of other ministries; (5) co-ordinating the work of political advisors; (6) planning and organising consultations and preparing opinions within the scope of the minister's activities; (7) analysing and giving opinions on documents submitted for the minister's signature; (8) creating and co-ordinating information and media policy; (9) conducting the minister's work agenda; (10) co-ordinating the circulation of correspondence to the minister; and (11) giving opinions on proposed visits and meetings of the minister and on the accordance of drafts of speeches prepared by other units with governmental goals. In performing its work programme, the political cabinet co-operates closely with secretaries and undersecretaries of state and with civil servants in the ministry. The main rule of its functioning is the co-operation of political and civil service spheres in the professional realisation of the government's tasks. ${ }^{20}$

Generally, political cabinets are relatively small in comparison to the civil service, which is oriented towards everyday management of ministries. Oftentimes, members of political cabinets do not have enough knowledge to give proper advice, which may limit their role. However, usually after a change of government, the role of political cabinets is for some time quite important. To avoid conflicts between civil servants and political advisors, as a rule, members of political cabinets are not allowed to give any orders to civil servants. Only a minister (deputy minister) can do so. It is the task of the minister to dissolve potential conflicts between the two groups.

The regulations of the Ministry of the Economy and the Ministry of Regional Development include rules that must be obeyed by persons occupying political posts. ${ }^{21}$ They should act in a law-abiding manner, strengthen the confidence of citizens, and care about the image of the state and the government. They should also uphold the principle of the civil service's political

Biuletyn Informacji Publicznej Kancelarii Prezesa Rady Ministrów [Public Information Bulletin of the Chancellery of the Prime Minister]: http://bip.kprm.gov.pl/bip.

Biuletyn Informacji Publicznej Ministerstwa Środowiska [Public Information Bulletin of Ministry of the Environment]: http://www.mos.gov.pl/bip/index.php?idkat=43.

On 31 October 2005 the Ministry of Economy and Labour was divided into the Ministry of Economy and the Ministry of Regional Development. Labour affairs were taken over by the Ministry of Labour and Social Policy. 
neutrality. Ministers cannot use their post and public resources to help attain the goals of political parties or of the interest groups they belong to. They should strengthen the coherence of the Council of Ministers, perform their tasks with due care, rationally administer state property and public finance and, if necessary, submit themselves to investigation and control procedures. They should guarantee openness and transparency in relations with the public and not allow suspicions to arise that private interests are being pursued in public activity. ${ }^{22}$

There are no specific sanction mechanisms for infringement of these rules. It has happened in the past that public pressure in cases of non-compliance with ethical rules has lead to the resignation or dismissal of members of a political cabinet.

It is difficult to predict future developments concerning the regulation of political cabinets. A broader perspective to properly assess the process is needed. A comprehensive regulation concerning the political cabinet would be useful.

\section{Public Opinion}

The public perception of political advisors is influenced by allegations of abusing posts and corruption. For example, an advisor to the Deputy Minister of Defense was accused of demanding financial advantages from foreign firms and taking part in tenders organised by the ministry. ${ }^{23}$ Also the director of the political cabinet of the Minister of Internal Affairs and Administration breached the anti-corruption law by sitting on the boards of governors of companies. Other members of that cabinet also breached the anti-corruption law. ${ }^{24} \mathrm{~A}$ recently nominated director in the Ministry for the Environment had to resign due to accusations in two criminal lawsuits. ${ }^{25}$

There are also allegations concerning members of political cabinets having obliterated the borders between political and civil service roles. As a result, "support for the governance process is still provided in an unprofessional capacity by an unprepared bureaucratic apparatus or, often, is not provided at all".26 The best persons are assigned by the minister to managerial posts in the civil service of the ministry. Consequently, political cabinets often gather together the political friends of a minister, i.e. individuals who did not manage to get elected to parliament. Political advisors assume the competencies of their superiors and try to influence the civil service sphere. ${ }^{27}$

There are also views that political cabinets are necessary elements of a robust public administration. Some are in favour of increasing the number of advisors in political cabinets and

Biuletyn Informacji Publicznej Ministerstwa Gospodarki i Ministerstwa Rozwoju Regionalnego [Public Information Bulletin of Ministry of Economy and Ministry of Regional Development]:

http://bip.mgpips.gov.pl/organy+i+osoby+sprawujace+funkcje+i+ich+kompetencje/Gabinet+Polityczny/G abinet+polityczny.htm.

"Doradca Szeremietiewa oskarżony" [Szeremietiew's Advisor Accused] in Wprost, 24 sierpnia 2002 r.: http://www.wprost.pl/ar/?O=28461.

B. Kittel, „Doradca z przeszłościa” [Advisor with a past] in Rzeczpospolita, 29 lipca 2003 r.

M. Sterlingow and M. Was, „Minister Szyszko i bezkarni drwale” [Minister Szyszko and unpunished lumbermen] in Gazeta Wyborcza: http://serwisy.gazeta.pl/kraj/2029020,34308,3028183.html.

M. Kulesza and A. Barbasiewicz, Functions of Political Cabinets, op. cit., p. 41.

Ibid., p. 41. 
staffing them with specialists in different fields who enjoy the minister's confidence. ${ }^{28}$ Political cabinets are a barrier against the infiltration of a "political element" in the civil service corps. ${ }^{29}$

Members of the civil service corps are bound by the Code of Ethics, which assembles standards of behaviour derived from civil service values as defined in article 153 of the Constitution and in the Civil Service Law. The Code of Ethics includes the obligation to follow service procedures as a matter of professionalism. A member of the civil service corps should be accountable for decisions and be politically neutral and impartial. ${ }^{30}$

It is worth mentioning that on 3 October 2005 Lech Kaczyński, then a presidential candidate, presented a code of ethical behaviour for members of government, secretaries and undersecretaries of state, heads of central governmental offices and members of political cabinets. This code proposes rules for selecting and evaluating candidates for public posts. It establishes principles of relations with the media, and shows how to organise foreign trips with the participation of advisors, which requires the agreement of the Prime Minister. ${ }^{31}$ As Lech Kaczyński has since become the President of Poland, it is now quite possible that this document will be given a more formal status.

To recapitulate, we may say that one of most serious problems for the current Polish public administration is that of proper relations between the political and civil service spheres. The creation and legal regulation of political cabinet functions represent an attempt to solve this dilemma.

Statement of Minister J. Widzyk in the discussion, „Wokół raportu W. Filipowicza 'Służba cywilna III RP: zapomniany obszar'" ["Surrounding the Report of W. Filipowicz: 'The Civil Service of the III Republic of Poland: a forgotten area'"], 16 April 2004, Fundacja im. Stefana Batorego, Warsaw, p. 16. Similar opinion concerns Maria Gintowt-Jankowicz, Director of the National School of Public Administration, ibid., pp. 19-20.

Statement of Jan Pastwa, Head of the Civil Service, ibid., p. 19.

See Zarządzenie nr 114 Prezesa Rady Ministrów z dn. 11 października 2002 r. w sprawie ustanowienia Kodeksu Etyki Służby Cywilnej [Order 114 of the Prime Minister of 11 October 2002 on the Civil Service Code of Ethics] in Monitor Polski z 2002 r., no. 46, poz. 683. 


\section{Bibliography}

\section{Primary Sources}

Constitution of the Republic of Poland of 2 April 1997: http://www.sejm.gov.pl/prawo/konst/angielski/kon1.htm

Ustawa z dn. 16 września 1982 r. o pracownikach urzędów państwowych [Law on Employees of State Offices of 16 September 1982], Dz. U. Z 1982 r., no. 31, poz. 214, Dz. U. Z 1982 r., no. 31, poz. 214

Ustawa z dnia 8 sierpnia 1996 r. o organizacji i trybie pracy Rady Ministrów oraz o zakresie działania ministrów [Law on the Organisation and Rules of Procedure of the Council of Ministers and on the Sphere of Competence of Ministers], Dz. U. z 1999 r. no. 82, poz. 929

Law on the Civil Service of 18 December 1998: http://www.usc.gov.pl/gallery/65/655.doc

Rozporządzenie Rady Ministrów z dnia 28 marca 2000 r. w sprawie zasad wynagradzania $i$ innych świadczeń przysługujących pracownikom urzędów państwowych zatrudnionym w gabinetach politycznych oraz doradcom lub pełniącym funkcje doradców osób zajmujących kierownicze stanowiska państwowe

[Council of Minister's Regulation of 28 March 2000 on remuneration and other benefits for employees of state offices employed in political cabinets and for advisors of persons who act as executives in state positions], Dz.U. z 2000 r., no. 24, poz. 296

Derdziuk Z. et al., Raport z przeprowadzonej analizy $i$ oceny tworzenia służby cywilnej (sierpień-wrzesień 1997) [Report of the analysis conducted and an evaluation of the establishment of the Civil Service (August 1996-September 1997)], Warsaw, February 1998

Komunikat po Radzie Ministrów [Statement from the Council of Ministers' Meeting], 26 October 2001: http://www.kprm.gov.pl/1937_2368.htm

Program uporządkowania i ograniczenia wydatków publicznych [Programme for restructuring and limiting public expenditure], Rada Ministrów, Warsaw, October 2003

Raport z realizacji „Programu uporządkowania i ograniczenia wydatków publicznych” [Report on the realisation of the "Programme for restructuring and limiting public expenditure"], Rada Ministrów, Warsaw, May 2005

Zarządzenie nr 114 Prezesa Rady Ministrów z dn. 11 października 2002 r. w sprawie ustanowienia Kodeksu Etyki Służby Cywilnej [Order 114 of the Prime Minister of 11 October 2002 on the Civil Service Code of Ethics] in Monitor Polski, z 2002 r., no. 46, poz. 683

Kodeks Prezydencki postępowania etycznego dla Premiera i Ministrów [Presidential Code of Ethical Conduct for the PM and http://www.lechkaczynski.pl/article.php?id=134\&p=materialy

Public Information Bulletin of the Chancellery of the Prime Minister: http://bip.kprm.gov.pl/bip

Public Information Bulletin of the Ministry for the Economy and the Ministry of Regional Development: http://bip.mgpips.gov.pl/organy+i+osoby+sprawujace+funkcje+i+ich+kompetencje/ Gabinet+Polityczny/Gabinet+polityczny.htm

Public Information Bulletin of the Ministry for the Environment: http://www.mos.gov.pl/bip/index.php?idkat $=43$ 


\section{Secondary Sources}

Bach-Golecka D., "The Civil Service and Political Authority in Government Administration" in: The Polish Yearbook of the Civil Service 2005

Burnetko K., Służba Cywilna w III RP: punkty krytyczne [The Civil Service in the III Republic of Poland: critical points] in: Raport Fundacji im. Stefana Batorego, 2003.

Czaputowicz J., "The Civil Service in Poland - between Politicization and Professionalization" in: The Polish Yearbook of the Civil Service 2005

Górski A., "Civil servans czy politicus servans - w okresie międzywojennym i obecnie", [Civil servants or political servants - in the interwar period and now] in: Służba Cywilna, no. 3/2002

Górski A., "The Civil Service Act of 18 December 1998 in the Light of Civil Service Acts of 1918-1922" in: The Polish Yearbook of Civil Service 2002

"Doradca Szeremietiewa oskarżony" [Szeremietiew's Advisor Accused] in: Wprost, 24 August 2002: http://www.wprost.pl/ar/?O=28461

Kittel B., "Doradca z przeszłością" [Advisor with a past] in: Rzeczpospolita, 29 July 2003

Kulesza M. and A. Barbasiewicz, "Functions of Political Cabinets" in: The Polish Yearbook of the Civil Service 2002

Sterlingow M. and M. Wąs, "Minister Szyszko i bezkarni drwale" [Minister Szyszko and unpunished lumbermen] Gazeta Wyborcza: http://serwisy.gazeta.pl/kraj/2029020,34308,3028183.html

Zapis dyskusji wokół raportu W. Filipowicza „Służba cywilna III RP: zapomniany obszar”, [Discussion surrounding the Report of W. Filipowicz: "The Civil Service of the III Republic of Poland: a forgotten area"], Stefan Batory Foundation, Warsaw, 16 April 2004 


\title{
PORTUGAL
}

\author{
José Alexandre Guimarães de Sousa Pinheiro \\ Senior member of the Portuguese Data Protection Authority \\ Portugal
}

\section{Portuguese Constitution}

\subsection{The Portuguese Constitution does not include any specific provision for political advisors}

Concerning national political bodies, the Constitution only mentions the state organs: the President, parliament (Assembleia da República), the government and the courts (article 110). Members of these organs are representatives of the sovereignty of the state, not political advisors.

As regards the functioning of parliament, the Constitution establishes the need for a permanent body of civil servants and provides for specialists to be contracted on a temporary basis, whose task is to provide technical assistance to the members of parliament (article 181).

In the section relating to the government, the Constitution does not make reference to special bodies of either political advisors or civil servants.

1.2 With regard to the public administration, the Constitution implicitly establishes a clear separation between political advisors and civil servants. This is not done directly, because the Constitution does not mention political advisors, but indirectly by mentioning the competences and functions of the public administration

In this regard, the main characteristics of the public administration are as follows:

- $\quad$ democratic decentralisation within the state (article 6.1);

- administrative bodies and civil servants in compliance with the Constitution and the law, respecting the principles of equality, proportionality, justice, impartiality and good faith (article 266.2); and

- $\quad$ civil servants, other state employees and other public entities in pursuit of the public interest, as defined by the competent bodies of the administration (article 269.2).

In none of the above provisions does the Constitution envisage any kind of connection between civil servants and political parties or other such political associations.

In conclusion, the Constitution does not identify an autonomous category of political advisors.

1.3 Based on the principle of separation of powers (article 111), the Constitution draws a clear distinction between the political ambit and the administrative one. This principle can best be safeguarded by preventing the encroachment of political advisors on administrative areas

The government is the "body which conducts the general policy of the country and the leading body of the public administration" (article 182). In spite of this, there is no overlap between the government and the action of political advisors. The Prime Minister and ministers are obviously entitled to appoint high- ranking civil servants, such as directors general. Once in office, these 
civil servants are answerable to members of the government and not to any kind of political advisors. Consequently there are no direct links in the Constitution between political advisors and civil servants.

\section{$2 \quad$ Political Advisors under the Law}

\subsection{It is difficult under Portuguese law to establish a definition of political advisor}

As regards the government, the laws make reference to chiefs of staff, assistants and consultants, but never specify clearly the nature of their functions, i.e. whether they are technical or political. Given the important number of assistants and consultants working for different governments supported by different parties, it is difficult to make a clear definition of these functions.

Within parliament the decision to recruit political advisors depends on each parliamentary group. The work to be done by these advisors is basically of a political nature because, in principle, the civil servants working in parliament should provide technical assistance to every parliamentary group.

Traditionally, political parties have closer ties with parliamentary political advisors than with political advisors in the government.

According to the law, the rules for recruiting political advisors for parliament and for government are different.

\subsection{With regard to parliament, the law (Law No 28/2003) establishes the following:}

- $\quad$ Parliament provides all of the necessary technical and logistical assistance through its own staff to political parties with elected representatives, parliamentary groups and parliamentary commissions.

- $\quad$ All parliamentary groups have their own office staff partly financed by parliament, and their composition depends on the number of elected members (article $46.1, b$ ); members of the staff are recruited by political parties.

- A parliamentary group with at least two members of the elected parliament can appoint a chief of staff financed by parliament (article 46.1, a).

- At the beginning of every legislature, parliamentary groups should inform parliament about their staff, professional categories and salaries (article 46.2).

- The law establishes limits for the salaries of political advisors financed by parliament (article 46.4 and 46.5).

- Parliamentary groups are entirely responsible for nominating and dismissing political advisors (article 46.6).

- Each parliamentary group receives an annual subsidy for operational expenses (article 47.4).

\subsection{The main goal of the above-mentioned law is to provide basic conditions for political parties with representatives in parliament to carry out their work.}

In this context, a distinction is made between civil servants paid by parliament and political advisors contracted by parliamentary groups.

The method adopted has proved efficient in maintaining the separation between political advisors and civil servants. 
2.4 Members of Parliament shall abide by the legal provisions preventing them from being civil servants. A parliamentary Commission of Ethics has been established as a permanent body empowered to, inter alia (article 39 of the Parliamentary Act):

- verify incompatibilities of the functions of a member of parliament and his/her capacity to perform duties and the like, in accordance with the law (no. 2, a);

- $\quad$ maintain a register of the personal interests of members of parliament (no. 2, b); and

- $\quad$ decide concerning any possible conflict of interest (no. 2, d).

$2.5 \mathrm{It}$ is also possible to investigate relations between members of parliament or political advisors and civil servants in commissions of inquiry. The Constitution allows parliament to set up these ad hoc commissions for the sole purpose of verifying that the law is being fulfilled

Like the courts, parliament can play a role in controlling the separation between civil servants and the political branch.

2.6 As regards the government, Decree-Law no. 262/88 establishes the most important rules about recruitment and functions of political staff. According to the law, political staff does not constitute a special category of civil servants

The most important features of political staff according to the law are as follows:

- Governmental staff is composed of a chief of staff, assistants and a team of secretaries (article 2.1).

- $\quad$ Specialists and technical advisors can be called on to carry out specific functions (article 2.2 and 2.3).

- The chief of staff is empowered to co-ordinate the office and to establish the required connections with the administrative bodies under the minister's responsibility (article 3.1).

- Assistants are required to provide technical assistance to members of the government (article 4.1).

- Members of staff can be freely appointed and dismissed by members of the government (article 6.1).

- Members of staff are subject to the same rules and regulations governing civil servants, in particular the rules of secrecy regarding their own work or knowledge acquired in the performance of their duties (article 8.1). 
2.7 The Decree-Law only mentions technical advisors, but these provisions are obviously used to appoint political advisors with several functions. Such advisors can build bridges between political parties, members of parliament and other institutions. However, the Decree-Law is clear in prohibiting any direct interference on the part of political advisors in the activity of administrative bodies. Only the chief of staff is entitled to establish connections between the office and those bodies

\section{Civil Servants under the Law}

3.1 Law 2/2004 regulates the personal status of high-ranking civil servants. This law is also applied at the local government level, in accordance with the terms set out by Decree-Law 93/2004

According to the law, high-ranking civil servants are those entitled to direct, manage, co-ordinate and control public bodies (article 2.1). The law establishes differences among these civil servants. There are two levels - high and intermediate - and within each of these levels there are different degrees of hierarchy, powers and responsibility (article 2.2).

The highest-ranking civil servants include directors-general, secretaries-general, the General Inspector and the President (article 2.3). At the intermediate level, the law mentions assistant directors and deputy directors (article 2.3). In the Portuguese system, directors-general can be removed at the will of ministers.

\subsection{According to the same law, high-ranking civil servants are to ensure that the} powers of the public bodies they are responsible for will be developed in such a way as to promote the general welfare of the public (article 3)

Guidelines for the administrative function carried out by high-ranking civil servants are defined in the programme of government and by the member of government responsible for that specific area (article 3).

High-ranking civil servants are to act in conformity with ethical principles, which imply acting in the public interest, respecting principles and fundamental constitutional values, such as legality, justice, impartiality, responsibility, proportionality, transparency and good faith (article 4).

The necessary accountability of administrative services explains the concept of management by objectives (article 5.1). The law mentions explicitly the need for setting long-term objectives and for co-ordinating all of the resources involved (article 5.1).

The actions of high-ranking civil servants are to be governed by specific criteria, such as:

- quality;

- $\quad$ efficiency,

- $\quad$ simplified procedures;

- $\quad$ co-operation to achieve a better relationship with citizens (article 5.2).

Civil servants in a position of leadership are to be evaluated according to a future law (article 14 of Law 2/2004). 
3.3 With regard to recruitment, the law states that highest-ranking civil servants may be chosen directly from among civil servants or individuals who are not civil servants, provided they have both a university degree and the requisite experience and skills for the function (article 18)

In order to thwart political abuses, it is strictly forbidden to appoint highest-ranking civil servants after the resignation of the government, in the period immediately prior to parliamentary elections, or before the parliamentary confirmation of a new government (article 19.6).

\subsection{Concerning the intermediate level, the law sets outs the following prerequisites} (article 20):

- $\quad$ university degree (article $20, a$ );

- $\quad$ passing grade in a specific course created to prepare the candidate for his/her new functions (article 20, b);

- $\quad$ required experience (article 20, c).

The directors of service and chiefs of division are chosen from among candidates with the adequate profile (article 21.1).

3.5 Concerning special duties, the law establishes that high-ranking civil servants have the following functions (article 34):

- $\quad$ to keep the government informed of all relevant issues involving the civil service in general (article 34, a);

- to ensure that acts adopted by ordinary civil servants respect the legitimate interests of citizens (article 34, b)

\subsection{For ordinary civil servants, the general rule of recruitment is a competitive} examination (Decree-Law 204/98, article 1). This examination ensures equal opportunities and equal conditions for every candidate and is open to everyone (article 5)

To be admitted to the civil service, candidates must fulfil the following requirements (article 29):

- $\quad$ be at least 18 years' old;

- $\quad$ have Portuguese nationality;

- $\quad$ have the necessary qualifications for the position;

- have been conscripted or, if not, be in compliance with legislation regarding military matters;

- $\quad$ be physically and psychologically able to perform the required duties.

3.7 Another important item related to administrative transparency is free access to documents issued by the public administration. According to the law (Law 65/93), principles of publicity, transparency, equality, justice and impartiality are guaranteed regarding public documents or public data (article 1). Every citizen has the right to be informed of the decisions adopted by the public administration in matters of direct interest to him/her (article 2.2). Concerning documents of a non-personal nature, the general rule is that everyone is entitled to have access to public data (article 7.1)

The Public Administration is obliged to make the public aware of (article 11): 
- $\quad$ all documents, as well as internal regulations or guidelines containing the framework of the administrative procedure involved in decision-making; and

- all documents that interpret the existing law, including the administrative procedure adopted.

\subsection{Another important legal instrument is the Carta Deontológica of the public service} (Resolution 18/93). The most important principles enshrined in this public charter are the following:

- $\quad$ The definition of civil servant includes everyone working for the public administration in a hierarchical system. The definition does not distinguish between temporary or permanent members (article 1).

- $\quad$ Civil servants are to act with neutrality in every case, always bearing in mind that all citizens are equal under the law. In consequence, political, economic and religious reasons should not interfere with their regular work (article 5).

- $\quad$ Civil servants are to abide by the rule of impartiality, acting according to the principle that every citizen is equal under the law and has the right to the same treatment, without positive or negative discrimination (article 10).

- $\quad$ Civil servants are not to pursue private aims when working for the public administration (article 19).

- Civil servants are to respect and follow the policies established by the national government, regional governments and local executives. They shall also interpret faithfully the guidelines defined by the political power of the day (article 22).

\subsection{An Ethical Charter of the Public Administration has similar principles:}

- $\quad$ The public interest must prevail over the interest of any individual or group.

- Public servants must comply with constitutional principles and the law.

- Justice and impartiality are crucial values guiding the actions of civil servants.

- $\quad$ No citizen shall be subject to any form of discrimination whatsoever under the law.

- Good faith is a fundamental principle that should command the actions of civil servants in all circumstances, including direct relationships with citizens.

4.1 The Constitution and the principal laws make a clear separation between civil servants and political advisors. However, the legal prerequisites are not always fulfilled, resulting in breakdowns in the system, such as the following:

- $\quad$ for reasons of political trust or urgency, ministers and secretaries of state try to control and monitor administrative activity directly through political advisors or other members of their staff;

- when political advisors and civil servants exercise the same functions, this can lead to conflicts and misunderstandings, with obvious repercussions on the work done;

- $\quad$ contracting new staff to work as advisors - political or otherwise - can cause costs to soar, without corresponding benefits;

- $\quad$ technical work carried out by political advisors sometimes suffers from a lack of coherence with the global system. 
4.2 Merely reading legal texts can give the reader the erroneous impression that the Portuguese system works perfectly in terms of the relationship between civil servants and political advisors. In spite of the existence of a clear dividing line between the two categories established by law, difficulties sometimes arise in defining the precise role of each group

Public bodies and administrative entities are required to fulfil their legal obligations and purposes as defined by the highest-ranking civil servants. These objectives can be jeopardised by political powers if they interfere with the ordinary work of civil servants by changing priorities previously defined at the administrative level. Very often, ministers and secretaries of state follow their own agenda in lieu of the reports approved by public bodies and even confirmed by the government. Political opportunity is the motive underlying the adoption of incoherent measures, thus causing serious problems for administrative work. Concepts like time and opportunity do not have the same meaning for civil servants and political advisors. The electoral factor is not an issue in the work of civil servants, whereas it is often the decisive factor in the decision-making process of political advisors. Problems can emerge when specific political options are not in harmony with certain legal measures or a broader framework crafted for the public sector. The real relationship of political advisors and civil servants is one of mutual suspicion and misunderstanding.

The government has created mechanisms to keep the principle of political opportunity firmly under control. For this purpose, the Legal Policy and Planning Office (GPLP) was created in 2001 - a public department within the Ministry of Justice charged with the important task of preparing legislation. The experience of this body has been positive, as it has ensured the coherence and better co-ordination of public policies in the area of justice.

4.3 With regard to work carried out within the public sector, due consideration for the experience and know-how of civil servants is sometimes not given. The problem is always the same: more study means more time. The specialised reports and work undertaken by civil servants cannot easily be replaced by political advisors, for whom immediate political needs often require rapid solutions

On the other hand, there are some tasks that are beyond the capacity of both civil servants and public advisors. In these circumstances, private outsourcing could constitute the best option. Both the government and the public administration can turn to private companies.

4.4 Civil servants are the link between different governments and distinct political parties. If each party has a specific policy for a certain area, it is crucial to establish the necessary connections between the new policy and previous ones. Civil servants and political advisors have different cultural profiles, which are defined by electoral needs. In general, civil servants tend to propose long-term policies, beyond the period of political tenure, whereas political staff are more focused on short-term programmes

Another consequence of the different cultural profiles is a different approach to changes and to public reforms. In this regard, political advisors are more likely to propose new measures. 
4.5 The expression political advisor in Portugal requires a careful interpretation. A large percentage of the political staff working with members of the government is recruited within the public administration. The same person can be both a civil servant and, on occasion, a political advisor. The person does not resign as a civil servant. After having worked as political advisors, civil servants can rejoin their service. In a sense, we are dealing with a dual personality - part Dr. Jekyll, part Mr. Hyde (the reader is left to decide which character corresponds to which function)

\subsection{The problems identified above should be taken into consideration in order to} streamline the relationship between the two categories studied in this report. However, the legal system, which clearly separates the role of both categories - civil servants and ministers - cannot be a reason for failure on the part of ministers to establish a close relationship with public bodies

\section{5}

\section{Conclusions}

A number of conclusions can be drawn from the above comparison between political advisors and civil servants:

- $\quad$ Portuguese law establishes a clear separation between the two categories.

- To guarantee democratic safeguards, the connections between the government and the public administration are closely regulated by law.

- It is not possible, according to the law, for a political advisor or a member of the political staff to interfere with the regular administrative work carried out by civil servants.

- $\quad$ Political advisors do not have the power to appoint high-ranking civil servants.

- $\quad$ The high-ranking members of the public administration are not entitled to pass political measures; it is part of their function to give policy advice but not political advice.

- Neither the Constitution nor the law forbids civil servants from becoming members of political parties or from taking part in political actions outside the sphere of their working life. However, the law forbids any lack of impartiality.

- $\quad$ Free access to administrative documents constitutes an important means of preventing political advisors from exerting any influence on administrative tasks, for example to spend money in a party's political stronghold.

- $\quad$ Awareness by the public of the administrative decision-making process is another way of reinforcing the principle of transparency.

- In practise, it is possible for the political staff to influence the everyday work of the public administration, but by law this kind of behaviour is not allowed.

No decisions made by Portuguese courts on this issue have been analysed in this report.

In spite of legal measures ensuring a clear separation between civil servants and political advisors, doubts sometimes arise in the press and in the minds of the general public about the way in which the legal system is implemented. When this occurs, it normally concerns the criteria used to appoint high-ranking civil servants, who very often are important members of the political party in power. These criteria need to be more specific, as in practice it means that political advisers/sympathisers can be appointed to senior civil service positions.

The guidelines for a more transparent relation between political power and civil servants should bear in mind not only the cultural aspects of each country, but also the need for a system of laws that clearly defines limits and rules. The executive branch must be controlled not only by the public and the media, but by parliament as well. In this complex web of checks and balances, the 
GOV/SIGMA(2007)2/REV1

main principle to be guaranteed is the effective separation of powers, preventing governmental hegemony. 


\title{
SPAIN
}

\author{
Antonio Natera-Peral \\ Francisco Javier Ruiz-Martínez \\ University Carlos III Madrid \\ Spain
}

\section{Country Background}

According to the Spanish Constitution of 1978, the state is territorially organised into four levels of government: municipal, provincial, autonomic (regional) and central public administrations. The autonomic public administration has a greater degree of independence, including legislative power and self-government attributions. Municipalities and provinces are both part of the local government level and do not have such powers, although they do have regulatory power within the limits set by law. Moreover, they all extend themselves through administrative organisations of various kinds, creating very complex intergovernmental relations. This gives some scholars the idea of defining the Spanish government system as a sort of administrative "archipelago" (Table 1).

The Constitution allowed the division of the entire state into regional units, referred to as autonomous communities, through a process of devolution of powers. The basic institutional norm of each autonomous community is its own Statute of Autonomy, which is akin to a regional constitution. This autonomous organisation comprises a Legislative Assembly, elected by universal suffrage; a Council of Government having executive power, with the Council President elected by the Assembly; and a High Court of Justice, which is the superior judicial body in the territory of the autonomous community.

By 1979, Spain had approved a new Constitution and faced the challenge of implementing the new structures and institutions mentioned in the Constitution. This meant replacing the traditional unitary territorial structure with a new form, legally known as autonomic. Indeed, the term autonomic hid an administrative federal structure, which many opposed (the army and the most conservative political and economic elite, including the monarchists). Since the leading motive of the constitutional bargain consisted of obtaining general consensus, a formula to gain everyone's support was introduced. The final agreement led to the creation of the autonomous communities $^{32}$.

All of the autonomous communities depend financially on both their own incomes and the central state budget, although the funds for each community are based on a percentage of income in accordance with a specific financial system. As a consequence, the communities all maintain and organise their own civil services, their own systems of recruitment, and their own way of appointing top (political or not) civil servants.

The distribution of powers and functions is contained in the Constitution ${ }^{33}$. Some specific areas are exclusively reserved to the central government ${ }^{34}$, and the autonomous communities do not

However, I would consider it accurate to use the term "federal monarchy" to describe the Spanish political form of government.

Specifically in articles 148 and 149.

Significantly, reserved to the central government are issues related to nationality, international affairs, foreign security and defence, monetary system, foreign trade, immigration control, judicial administration, and statutory reform in the autonomous communities. 
share them in any way. On some other matters they have the power to execute national legislation and to adopt their own regulations. Finally, in other areas the autonomous communities have more attributions and are able to pass their own legislation.

This is the case of areas such as self-government institutional and administrative organisation, culture, housing, environmental protection, public works inside the limits of its territory, regional roads, education, health, social services and employment promotion, among others. The actions carried out in all of these areas are the responsibility of the autonomic civil service.

Some similar principles guide the local level of government (municipalities and provinces), although here accounting difficulties become the rule. The dramatic differences between the enormous administrations of the large cities and the tiny ones of villages, which are both ruled by the same basic legislation, have made it almost impossible to distinguish between political appointees and those who have obtained their posts by means of an examination at local level. 
Table 1: Spanish Administrative System: an Example of structural Complexity

\begin{tabular}{|c|c|c|c|c|c|}
\hline $\begin{array}{l}\text { Territorial } \\
\text { Level }\end{array}$ & $\begin{array}{l}\text { Level of } \\
\text { Government }\end{array}$ & Structure of Government & $\begin{array}{l}\text { Peripheral Public } \\
\text { Administration }\end{array}$ & $\begin{array}{l}\text { State and/or Public- } \\
\text { Sponsored Bodies }\end{array}$ & Public Administration Abroad \\
\hline $\begin{array}{l}\text { Central State } \\
\text { (national) }\end{array}$ & $\begin{array}{l}\text { Central } \\
\text { Administration (or } \\
\text { General Public } \\
\text { Administration of the } \\
\text { State) }\end{array}$ & $\begin{array}{l}\text { - President of the } \\
\text { Government } \\
\text { - Council of Ministers } \\
\text { - Ministries }\end{array}$ & $\begin{array}{l}\text { Peripheral Administration } \\
\text { - Government Dels. in the } \\
\text { Autonomous Communities } \\
\text { - Government Deputy-Dels. in } \\
\text { the counties } \\
\text { - Territorial administration of } \\
\text { Ministries \& State- Sponsored } \\
\text { Bodies }\end{array}$ & $\begin{array}{l}\text { Institutional Administration } \\
\text { - State Agencies } \\
\text { Sponsored Bodies } \\
\text { - Public Companies } \\
\text { - Social Security } \\
\text { Management Boards }\end{array}$ & $\begin{array}{l}\text { Foreign Administration of the } \\
\text { State } \\
\text { - Embassies } \\
\text { - Foreign Permanent } \\
\text { Representations } \\
\text { - International Delegations } \\
\text { - etc. }\end{array}$ \\
\hline $\begin{array}{l}\text { Regions } \\
\text { (regional) }\end{array}$ & $\begin{array}{l}\text { Autonomous } \\
\text { Communities }\end{array}$ & $\begin{array}{l}\text { - President of Autonomous } \\
\text { Community } \\
\text { - Council of Government } \\
\text { - Government Departments } \\
\text { (Consejerías) }\end{array}$ & $\begin{array}{l}\text { Peripheral Administration (mainly } \\
\text { in the Autonomous Communities } \\
\text { with a single county) }\end{array}$ & $\begin{array}{l}\text { - Sponsored Bodies } \\
\text { - Public Companies } \\
\text { - Participation in other } \\
\text { kinds of state-sponsored } \\
\text { bodies (consorcios, } \\
\text { fundaciones, etc.) }\end{array}$ & \\
\hline $\begin{array}{l}\text { Counties } \\
\text { (provincial) }\end{array}$ & $\begin{array}{l}\text { Supra-municipal } \\
\text { Local Administration } \\
\text { (Diputaciones, } \\
\text { Cabildos) }\end{array}$ & $\begin{array}{l}\text { - President of County } \\
\text { - Commission of } \\
\text { Government } \\
\text { - Government Directorates }\end{array}$ & & $\begin{array}{l}\text { - Sponsored Bodies } \\
\text { - Public Companies } \\
\text { - Participation in other } \\
\text { kinds of state-sponsored } \\
\text { bodies (consorcios, } \\
\text { fundaciones, etc.) }\end{array}$ & \\
\hline $\begin{array}{l}\text { Municipalities } \\
\text { (municipal) }\end{array}$ & $\begin{array}{l}\text { Town/City Halls } \\
\text { (Ayuntamientos) }\end{array}$ & $\begin{array}{l}\text { - Mayor } \\
\text { - Commission of } \\
\text { Government } \\
\text { - Councillor Departments } \\
\text { (Concejalías) }\end{array}$ & Districts (only in large cities) & $\begin{array}{l}\text { - Sponsored Bodies } \\
\text { - Public Companies } \\
\text { - Participation in other } \\
\text { kinds of state-sponsored } \\
\text { bodies (consorcios, } \\
\text { fundaciones, } \\
\text { mancomunidades, } \\
\text { comarcas, etc.) }\end{array}$ & \\
\hline
\end{tabular}

$\Rightarrow$ Other areas in the "Spanish administrative archipelago": the "Administraciones Mediales del Estado"; the "Administración Consultiva"; the "Comarca" (Catalonia y Aragon), the sub-municipal administration (Galicia); "autonomous entities, NGOs and other quasi-public organisations ('para-administration')", etc. 
Although the Spanish state structure described above seems to be an entirely finished and closed one, some very important tasks remain to be carried out. One of the key questions in the current managerial modernisation debate is related to finding a better way of regulating the competencies of the autonomous communities and in consequence elaborating a new design of the state budget among autonomous communities and municipalities. The inability to resolve this matter is resulting in subsidiarity ${ }^{35}$ problems, such as inequality of salaries for all civil servants and differences in fiscal accountability among the various levels of territorial government, which are in turn leading to some constitutional controversy and demands for institutional reorganisation. In this paper we will focus only on permanent civil servants and political appointees as political advisors at the central level of government, that is, in the Central Public Administration (CPA) $)^{36}$, in view of the impossibility of obtaining accurate information on this subject at the territorial levels of government.

\section{During the last two decades the CPA has faced a deep transformation, affecting most of its administrative and personnel structures. We can point out four interdependent processes:}

- Political and administrative decentralisation: The establishment and consolidation of the autonomous communities' public administrations during the 1980s had a dramatic impact on the CPA. The traditional monopoly of public resources management was replaced by a decentralised federal-like model in which the autonomous communities controlled most of the public expenditure. By the 1990s the transfer or devolution of powers from the central government to the autonomic governments was speeded up, and with it the transfer of financial and personnel resources was completed in areas such as education, health and culture. Thus the CPA passed from managing $90 \%$ of public expenditure to only $50 \%$, together with undergoing a large reduction of its civil service: in less than a decade, the CPA decreased its number of civil servants from almost one million to just over half a million, that is, to less than $25 \%$ of all public sector employment in Spain (see Table 2).

- Consolidation of the (Latin) welfare state model: This consolidation meant a dramatic increase in the Spanish public administration, mainly in areas such as education, health and social services, thus raising dramatically the number of public employees. As a consequence, social expenditure approached western European standards, and public employment increased by $50 \%$, reaching two and a half million (see Table 2), although most of the new jobs were created at local and autonomic levels. Nevertheless, the entire number of public employees still places Spain under the EU 15 average, with just 54.5 public employees per 1000 inhabitants. ${ }^{37}$

The "subsidiarity" concept is understood as expressed by the European Union: "The subsidiarity principle is intended to ensure that decisions are taken as closely as possible to the citizen and that constant checks are made as to whether action at Community level is justified in the light of the possibilities available at national, regional or local level."

In Spanish Administración Central del Estado.

Indeed, the massive arrival of more than four million immigrants in the past 15 years may have altered these figures, with in fact fewer than 54.5 public employees per 1000 inhabitants. 
Table 2: Spanish Public Sector Employees by Administrative Level

\begin{tabular}{lcc}
\hline & $\begin{array}{c}\text { Number of } \\
\text { Employees }\end{array}$ & $\%$ \\
\hline CENTRAL PUBLIC ADMINISTRATION & 542125 & 22.5 \\
Central Public Administration & 233364 & 9.7 \\
Law Enforcement & 113583 & 4.7 \\
Armed Forces & 115905 & 4.8 \\
Judicial Administration & 23681 & 1.0 \\
$\quad$ Public Companies and State-Sponsored Bodies & 55592 & 2.3 \\
AUTONOMOUS COMMUNITIES' ADMINISTRATIONS & 1196223 & 49.9 \\
UNIVERSITIES & 94704 & 3.9 \\
LOCAL ADMINISTRATIONS & 568127 & 23.7 \\
Town/City Halls & 488534 & 20.4 \\
Supra-Municipal Local Administration & 79593 & 3.3 \\
\hline TOTAL & $\mathbf{2 4 0 1 1 7 9}$ & $\mathbf{1 0 0 . 0}$ \\
\hline
\end{tabular}

Source: The authors have based these figures on public data provided by the Personnel Central Register of the Ministry of Public Administrations (July 2005).

- Integration of Spain into the EU: As from 1986, and mainly after the Treaty of Maastricht signature, the EU had a great impact on the CPA since the EU Member States were compelled to share sovereignty. This process brought a Europeanisation of public policies. Many institutions in the economic sector had to be monitored and regulated by EU institutions. Moreover, the management and implementation of European programmes was transferred from the CPA to autonomous communities and municipalities. Nevertheless, the CPA still keeps under its control the role of decision-maker and manager of the Cohesion Funds.

- $\quad$ Privatisation and outsourcing of public services and other public-supported services: These processes have been particularly significant. By the 1990s the Aznar governments had completed the privatisation of most public companies, some of which were especially important given their strategic and economic position (Endesa, Telefónica, Argentaria, etc.), although the process had already been begun under the González governments at the end of the 1980s. At the same time, the outsourcing of services helped to "slim" the CPA in favour of private organisations, either private companies and firms or NGOs and foundations providing or managing services of a public nature and paid from public resources.

All of these changes placed the CPA in a new position and gave a brand new role to its political, strategic and regulatory powers, which were becoming increasingly more important than its traditional managerial and implementing powers (Ballart and Ramiò, 2003). Three of these new powers can be underlined: 1) social and territorial homogenisation in the decentralised Spanish 
State; 2) sectoral and global co-ordination between regional and local public administrations and social and economic actors; and above all, 3) the role of a "think tank" keeping watch over the whole territory - as well as all sectors - throughout the entire policy process, envisaging possible problems and designing long-term strategies.

It is in this context, "at the helm more than rowing", where the role of political advisors, either civil servants or political appointees, becomes essential, as we will explain in this paper.

\section{The Role and Responsibilities of Permanent Civil Servants as Advisors}

The Spanish civil service model still keeps the basic characteristics of a recruitment system by examination, linked to the Weberian paradigm of merit bureaucracy. Accepted without discussion are civil servants' versatility to carry out different jobs within the same area, the permanent work contract, merit as a requirement for recruitment and promotion, and civil servants' impartiality and objectivity. Therefore it does not seem strange at all to discover that $90 \%$ of public employees in the CPA have permanent contracts and two out of three hold a permanent post by public appointment (see Table 3).

Table 3: Civil Servants in the Central Public Administration

\begin{tabular}{lcc}
\hline TYPES OF CIVIL SERVANTS & No. & $\%$ \\
\hline Permanent Civil Servants (permanent appointment and status) & 149707 & 64.2 \\
Permanent Contract Civil Servants (contractual status) & 64157 & 27.5 \\
Temporary Contract Civil Servants (contractual status) & 14403 & 6.2 \\
Non-permanent Civil Servants (political appointees) & 522 & 0.2 \\
Other types & 4575 & 1.9 \\
\hline TOTAL & $\mathbf{2 3 3} 364$ & $\mathbf{1 0 0}$ \\
\hline
\end{tabular}

Source: Prepared by the authors on the basis of public data provided by the Personnel Central Register of the Ministry of Public Administrations (July 2005).

The Spanish Constitution of 1978 devotes an entire article to the public administration, explaining its finality and its main governing principles, which should guide civil servants' actions. Nothing is said about the CPA structure, but this will be a matter of subsequent legislative development. Act 6/1997 on the CPA Organisation and Functions established the CPA basic structure through the simplification of previous norms devoted to this matter. At the same time, this Act made some changes in order to diminish the CPA peripheral administration, since many functions had been transferred to the autonomous communities as part of the above-mentioned devolution of powers. However, the Act regulating the civil service dates from 1984 (Act 30/1984) and has not yet been updated.

As in many other European countries, the political-tactical advisory role and technical assistance to politicians are widely developed in the civil service, and this responsibility falls on the shoulders of permanent civil servants. While exercising their advisory functions, civil servants must take a non-partisan position (by not providing support to electoral campaigns, not providing policy reports and recommendations to political parties, etc.), and they are obliged to provide loyal and honest advice based only on professional and technical criteria.

Among the 88 different kinds of advisor posts that we identified in the CPA, more than 1,000 posts included the title "asesor" (advisor). Permanent civil servants hold $71.4 \%$ of these posts. Most of these officials possess a university degree (see Table 4). 
Almost half of the advisory posts occupied by permanent civil servants are concentrated in five of the 16 current ministries: Finance and Treasury (105), Foreign Affairs (85), Justice (82), Presidency (143), and Labour and Social Affairs (150). If we examine the structure of these ministries, we discover that permanent civil servants playing the role of political advisors may take part in every kind of policy-making and at all different levels of the highest administration: political units, managerial units and administrative units. 
Table 4: Political Advisors in Central Public Administration: Permanent Civil Servants and Political Appointees (1 February 2006)

\begin{tabular}{|c|c|c|c|c|}
\hline Ministry & $\begin{array}{c}\text { High Permanent } \\
\text { Civil Servants as } \\
\text { Advisors }\end{array}$ & $\begin{array}{l}\text { Middle and Low } \\
\text { Permanent Civil } \\
\text { Servants as } \\
\text { Advisors }{ }^{39}\end{array}$ & $\begin{array}{l}\text { Political } \\
\text { Appointees } \\
\text { (special } \\
\text { advisors) }\end{array}$ & Total Advisors \\
\hline $\begin{array}{l}\text { Public } \\
\text { Administrations }\end{array}$ & 41 & 25 & 106 & 172 \\
\hline $\begin{array}{l}\text { Farming and } \\
\text { Fisheries }\end{array}$ & 27 & 11 & 9 & 47 \\
\hline Foreign Affairs & 74 & - & 11 & 85 \\
\hline Culture & 17 & 1 & 4 & 22 \\
\hline Defence & 9 & - & 9 & 18 \\
\hline $\begin{array}{l}\text { Finance and } \\
\text { Treasury }\end{array}$ & 100 & 1 & 4 & 105 \\
\hline $\begin{array}{l}\text { Education and } \\
\text { Science }\end{array}$ & 38 & 1 & 7 & 46 \\
\hline Public Works & 20 & 2 & 11 & 33 \\
\hline $\begin{array}{l}\text { Industry, Tourism } \\
\text { and Trade }\end{array}$ & 40 & 1 & 10 & 51 \\
\hline Home Affairs & 22 & - & 11 & 33 \\
\hline Justice & 72 & - & 10 & 82 \\
\hline $\begin{array}{l}\text { Environmental } \\
\text { Affairs }\end{array}$ & 12 & 2 & 6 & 20 \\
\hline Presidency & 69 & 5 & 69 & 143 \\
\hline Health & 26 & 2 & 7 & 35 \\
\hline $\begin{array}{l}\text { Labour and Social } \\
\text { Affairs }\end{array}$ & 62 & 66 & 22 & 150 \\
\hline Housing & 5 & 1 & 7 & 13 \\
\hline TOTAL & 634 & 118 & 303 & 1.055 \\
\hline
\end{tabular}

Source: The authors based the above figures on public data provided by the Sub-Directorate for Data Processing of the Ministry of Public Administrations (1 February 2006).

We must point out the key role played by ministerial cabinets - these collegial advisory units may vary in size but they are never very large and are always directed by a cabinet head. Indeed, the three most important advisory units of a ministry are the minister's cabinet, the cabinet of the secretary of state (deputy minister), and the general secretary's cabinet. Permanent civil servants and political appointees (as "special advisors") work together in these cabinets. Their functions consist of advising political officials on relations with the mass media,

Namely "B and C Groups". 
drawing up reports, co-ordinating political agendas and high-level meetings, facilitating relations with the legislative chambers, etc. (see Table 5).

Table 5: Traditional Ministry Model: top political units, managerial units and administrative units (Spanish terms) and their respective advisory units

\begin{tabular}{|c|c|c|c|}
\hline & Hierarchical position & Legal requirements & Joint advisory staff \\
\hline \multirow{2}{*}{$\begin{array}{l}\text { TOP POLITICAL } \\
\text { UNITS }\end{array}$} & Ministro & Political appointment & $\begin{array}{l}\text { YES (Cabinet and } \\
\text { single advisors) }\end{array}$ \\
\hline & Secretario de Estado & Political appointment & $\begin{array}{l}\text { YES (Cabinet and } \\
\text { single advisors) }\end{array}$ \\
\hline \multirow{5}{*}{$\begin{array}{l}\text { MANAGERIAL } \\
\text { UNITS }\end{array}$} & Subsecretario & $\begin{array}{l}\text { Permanent Civil Servant } \\
\text { (political appointee) }\end{array}$ & $\begin{array}{l}\text { YES (Technical } \\
\text { Cabinet) }\end{array}$ \\
\hline & Secretario General & Political appointment & YES (single advisors) \\
\hline & Director General & $\begin{array}{l}\text { Political appointment or } \\
\text { Permanent Civil Servant } \\
\text { (political appointee) }\end{array}$ & YES (single advisors) \\
\hline & $\begin{array}{l}\text { Secretario } \\
\text { Técnico }\end{array}$ & $\begin{array}{l}\text { Permanent Civil Servant } \\
\text { (political appointee) }\end{array}$ & YES (single advisors) \\
\hline & Subdirector General & $\begin{array}{l}\text { Permanent Civil Servant } \\
\text { (political appointee) }\end{array}$ & NO \\
\hline \multirow{3}{*}{$\begin{array}{l}\text { LEADING } \\
\text { ADMINISTRATIVE } \\
\text { UNITS }\end{array}$} & Jefe de Servicio & $\begin{array}{c}\text { Permanent Civil Servant (by } \\
\text { examination) }\end{array}$ & NO \\
\hline & Jefe de Sección & $\begin{array}{c}\text { Permanent Civil Servant (by } \\
\text { examination) }\end{array}$ & NO \\
\hline & Jefe de Negociado & $\begin{array}{c}\text { Permanent Civil Servant (by } \\
\text { examination) }\end{array}$ & NO \\
\hline
\end{tabular}

In the past 15 years the importance and prominence of the cabinets have increased very much, and consequently their organisational capacity and real power have also increased, and they have undertaken many other tasks besides simple advisory work. There is clear evidence of the central role of the cabinets, and in particular the minister's cabinet, in the design, implementation, monitoring and evaluation of public policies. The cabinets thus influence decisively the decision-making process in the CPA through their support or rejection of proposals sent for final decision to the Council of Ministers. Emphasis has been given to the link between these cabinets and the President of the Government Cabinet in increasing the rate of success in passing Bill proposals to the Council of Ministers.

This dynamic has brought about a sort of networking system among all of the cabinets, which on occasion may diminish the influence of managerial units in ministries and even "rob" designated decision-makers of their democratically legitimate functions.

\section{Roles and Responsibilities of Special Advisors}

Within the CPA a very reduced number of positions are held by non-permanent civil servants (political appointees and special advisors): only 522, i.e. $28.6 \%$ of the total number of posts 
under the "advisor" denomination. Moreover, most of them officials $(80.5 \%)$ belong to the "A Group" (university degree-holders).

These posts are characterised by being filled according to parameters of political confidence. These advisors depend on the direct confidence of the politician who appointed them and on the period of time that this politician holds office. Personal secretaries and individual advisors attached to ministers, secretaries of state, general secretaries and general directors make up this group of advisors. Likewise, special advisors are usually members of the ministerial cabinet, where they carry out governmental programming tasks and technical advice, with the assistance of permanent civil servants, for the co-ordination of public policies issued by the ministry.

In general, functions and tasks carried out by special advisors have higher political and strategic profiles than those carried out by permanent civil servants, and they are mainly focused on crisis simulation, conflict resolution and strategic innovation. The other main areas in which special advisors play a key role involve maintaining relations with the mass media, drawing up white and green papers, training politicians in communication skills, etc.

Most special advisors work in the Ministry of Public Administrations and, above all, in the Presidency of the Government (either the President's Office or the Ministry of the Presidency ${ }^{40}$ ). During the Suárez (1977-81) and Calvo Sotelo centre-right wing governments (1982), the presidential administrative framework was quite reduced and gathered together a small group of individuals popularly known as the "Moncloa ${ }^{41}$ plumbers". Once González, the Socialist Party leader, obtained power, the presidential administrative structure experienced considerable change, at both quantitative and qualitative levels. This pattern of growth went on in the Aznar (conservative) and Zapatero (socialist) governments, with an increasing number of advisors and of the tasks assigned to them. These changes were in line with the international tendency to turn managerial units attached to the Prime Minister (President of the Government in Spain) into larger and more powerful administrative organisations.

Very special consideration should be given to examining the presidential administrative structure that has been called the Presidency Cabinet. This cabinet is the key and main unit devoted to politically and technically advising the President of the Government in most of his/her work. The Cabinet of the Presidency has a director and a deputy director, and it is divided into several sectoral departments that mirror the ministerial network. The cabinet is currently split up into six policy departments: 1) Institutional Affairs; 2) International Politics and Security; 3) Analysis and Research; 4) Education and Culture; 5) Economics and Finance; and 6) Welfare and Social Issues. These departments are comprised of many staff members, but mainly special advisors. They have the task of collecting information about the proposed plans of each ministry in order to provide the President with enough information to allow him/her to co-ordinate the overall political action of the government.

The reports submitted to the President or to the deputy presidents are of three types:

a) Informative notes: short documents concerning an issue of interest to the President or deputy presidents;

b) Monographic reports: longer documents dealing in depth with a key issue on the President's policy agenda; and

Both terms have been used since 1977, at the complete discretion of the President of the Government, to describe the ministerial organisation supporting the President's administrative framework.

The Palacio de la Moncloa is the official residence of the President of the Government. 
c) The well known "Council of Ministers" folders: these reports constitute the main work of advisors. The folders contained reports drawn up by the Cabinet of the Presidency on the matters that must be decided by the Council of Ministers.

All of these reports allow the President to be in a privileged position when leading the work of the Council of Ministers, since he/she is the only one in possession of the correct information on everyone's activities and is therefore not dependent on the reports sent by ministers. As a consequence, the Cabinet of the Presidency is often perceived as an enemy of some of the ministers' proposals (Ortega, 1991). Its central position and its strategic situation and level of knowledge about the work of all decision-making rank units in the CPA have led many scholars to refer to this cabinet as a "shadow government", controlling and even managing some actions of ministries.

\section{Existing Training Programmes}

The training programmes offered to the CPA civil service are organised and delivered by the National Institute for Public Administration (INAP), which is a CPA state-sponsored body attached to the Ministry of Public Administrations. Among its functions is the provision of special programmes to train senior civil servants in new managerial methods and tasks. These programmes constitute a major change in the traditional training scope of Spanish senior civil servants, which had basically focused on a "juridical culture" complemented by some economic elements; this kind of training has now been abandoned in favour of training to prepare public managers.

The introduction of the post-bureaucratic model of provision of services based on the New Public Management (NPM) approach, which conceives of the citizen as a "client", has greatly influenced the renovation of many public organisations and has brought about new training demands and new tasks of public managers. Nevertheless, the traditional juridical bureaucratic model coexists together with the post-bureaucratic one, and has posed no problem to civil servants.

\section{Box 1: High managerial training for civil servants}

The Masters degree in Management and Analysis of Public Policies, offered by the University Carlos III Madrid and the (INAP), focuses on providing high level training for managers (permanent civil servants) in the Spanish public administrations (central, autonomic and local administrations) Its programme covers the following aspects:

- $\quad$ State of art approaches and techniques of public policy analysis and management;

- Most successful strategies, case studies and methods in current public management;

- New scenarios, different arenas, and innovative guidance for strategic public management: problems and specific developments in strategic and emerging public policies;

- Key significance of intergovernmental relations and networking for public policies in a global world;

- Executive skills applied to organisation and team leadership: strategic management, bargaining, promotion and management of reform, communications, networking management, conflict management and resolution, methods in the decision making process, intercultural abilities, etc.

In this connection, the INAP offers a large number of short-term training courses (http://www.inap.map.es/inapes/actfor.htm) as well as some long-term training courses and master degree programmes (see Box 1), such as the Masters in Management and Analysis of 
Public Policies, often in collaboration with many other public training institutions (mainly universities) and sometimes addressed to third country civil servants, especially those from Latin America.

\section{Comments on Likely Future Trends and Need for Reform}

We have already mentioned above the considerable growth of the Spanish Public Administrations in terms of the number of their functions and services, which has resulted in a great increase in the degree of complexity within the administrations and in financial and human resources. However, the last significant reform of the human resources framework was approved 20 years ago by Act 30/1984 (2 August 1984) on Measures to Reform the Civil Service. This act remains the main regulatory norm for regulating the public employment structure, even though it is considered quite unsatisfactory and obsolete by many scholars and senior civil servants.

Although the preparation of a Civil Service Statute was foreseen by the Spanish Constitution of 1978 as a key task, it was not started until 2004. The Commission for the Study and Preparation of the Civil Service Statute was set up by the Ministry of Public Administrations Order APU/3018/2004 (16 September 2004). The Commission has been given the task of gathering and reporting the opinions of all "stakeholders" involved in the civil service framework. This work is foreseen as the basic part of the impending pre-project for preparation of the Statute.

With regard to non-permanent civil servants (political appointees), the Commission's final report (MAP, 2005) points out concerns about the significant increase in recent years of the overall number of such appointees (especially and mainly in local public administrations and to a lesser degree in the autonomic administrations). The authors were also concerned to observe that their powers of political confidence and advice had grown and that special advisors were currently carrying out managerial and executive tasks that previously had been reserved to senior civil servants, that is, permanent civil servants. The Commission considers that the category "political advisor" must in fact be understood as exceptional in a civil service structure characterised by recruitment based on merit and by capacity verified by examination. In this sense, it proposes a tougher legal regulation of the requirements for the appointment of a special advisor in the impending Civil Service Statute so as to limit their numbers and to promote transparency with regard to their appointment and functions (see Box 2).

Finally, it has been argued that a professional code of practice and ethics inside the public administration needs to be prepared, similar to the Right Government Code drawn up by the Commission for political appointees through Ministry of Public Administrations Order APU/516/2005 (3 March 2005).

\section{Box 2: Suggestions made by the Commission for the preparation of the Civil Service Statute regarding political advisors}

The Commission considered that non permanent personnel, discretionally appointed and dismissed, must specifically carry out functions determined by law as political advice and that they must be dismissed immediately following the dismissal or resignation of the official who appointed them.. Therefore, the performance of political appointees should not be taken into consideration as additional merit for professional promotion or civil service accession.

The Commission also considered that the public administrations should be obliged to periodically provide information on the number of non permanent public employees and their functions, as well as their wages, their positions and the units to which these positions are attached. Moreover, they should be obliged to report any change that may occur with regard to such information.

(MAP, 2005: 237) 


\section{Further Referents}

Aja, E. (2003), El Estado Autonómico. Federalismo y hechos diferenciales, Alianza, Madrid.

Alba, C.R. y F.J. Vanaclocha (1997), El sistema político local: un nuevo escenario de gobierno, Universidad Carlos III de Madrid / BOE, Madrid.

Ballart, X. y C. Ramiò (2003), "Ciencia de la Administración”, Tirant lo Blanch, Valencia.

Baena, M. (2005), “Manual de Ciencia de la Administración”, Síntesis, Madrid.

Olías, B., ed. (1995), "La gestión de recursos humanos en las Administraciones públicas", Editorial Complutense, Madrid.

Ortega, L. (1991), "El gabinete del presidente del Gobierno" in: Documentación Administrativa, 226.

Ministerio de Administraciones Públicas/MAP (2000), Estructura orgánica y funciones de la Administración General del Estado, MAP, Madrid.

Ministerio de Administraciones Públicas/MAP (2005), Informe de la Comisión para la preparación del Estatuto Básico del Empleado Público, MAP, Madrid.

Registro Central de Personal (2005), Boletín Estadístico del personal al servicio de las Administraciones públicas, Ministerio de Administraciones Públicas, Madrid.

Villoria, M. y E. Del Pino (2001), "Manual de gestión de recursos humanos en las Administraciones públicas", Tecnos, Madrid. 


\title{
THE UNITED KINGDOM
}

\section{A difficult but constructive relationship}

\author{
Katharine Raymond \\ Former political adviser to the Minister of Education, and later to the Minister of the \\ Interior \\ United Kingdom
}

\section{Background}

In every country, the relationship between political advisers and civil servants is a difficult one. No one country has a perfect system and the association between the two groups can, on occasion, be laden with mutual suspicion and mistrust. However, tension between them, in the atmosphere of true democratic governance, can actually be a very positive thing. Of course, for any conflict to be constructive certain essential ingredients are required: honesty, respect, understanding and a willingness to learn and see other viewpoints. But the very best policies those that deliver the greatest benefits to the people - are often born from creative tension and productive argument.

I found this to be true in all three British ministries I worked in between 2000 and 2005. Civil servants would start working on a new policy with a firm and clear idea on how policy solutions should be developed; political advisers would start with another idea, or a different viewpoint. Eventually, both advisers and civil servants would find a compromise and very often, as a direct result of intense discussion and even argument, that policy would be a stronger one than either party had envisaged at the beginning. That was because the policy had been thoroughly tested, explored and researched from all angles and viewpoints. Importantly, political advisers and civil servants, having shared in the development of that policy, would have an equally strong investment and interest in its success.

\section{The Different Roles of Civil Servants and Political Advisers}

In the UK, most ministries have two or three political advisers. It is only the Prime Minister's Office that has as many as 15 or 20. Even a large department like the Home Office, which handles all interior affairs including crime and policing, immigration and asylum, criminal justice and prisons, had only one part time and three full time political advisers when I worked there in $2001-2004$.

Political advisers have 'privileged access' to ministers. In most ministries, even the most senior civil servants do not have the same high level of access as advisers. This is often because political advisers have worked closely with and known their ministers for a long time, often working for them while they were Members of Parliament in opposition to the government of the day, or through the Party to which both Minister and political adviser belong. Many political advisers come to government from a research job in the Party, or have previously worked for academic think tanks, charities or public affairs organisations.

In the UK, political advisers (or 'special advisers' as they are usually called) are classed as temporary civil servants, required to conduct themselves in accordance with a Code of Conduct for Special Advisers and with the Civil Service Code. The Civil Service Code, as it currently stands, came into force ten years ago and sets out the constitutional framework within which all civil servants work, and the values they are expected to uphold. In fact the Code forms part of the terms and conditions of employment of every individual civil servant, and that includes political 
advisers. The main elements of the Code, "to serve with integrity and honesty the duly elected government of the day", are the glue that binds political advisers and civil servants together.

But what are the differences in the roles and the functions of civil servants and political advisers, and how is the responsibility for providing ministers with policy advice shared between the two? These are difficult questions because, very often, the two roles have common characteristics. In theory, political advisers are employed to help ministers where the work of government and the work of the government party overlap, and it would be inappropriate for permanent and impartial civil servants to become involved.

\section{The UK Code of Conduct for Political Advisers}

The Code of Conduct for Special Advisers itself provides some examples of work a political adviser might do instead of civil servants:

- Review papers going to the Minister, drawing attention to any aspect which may have Party political implications and ensuring that sensitive political points are handled properly

- $\quad$ Contribute to policy planning within the department, including ideas which extend the existing range of options available to the Minister with a political viewpoint in mind

- $\quad$ Represent the views of a Minister to the media with a political slant added

However, on a day-to-day basis the roles can become confused. It is also the job of civil servants to advise ministers, and policy decisions cannot always be easily kept separate from political considerations. If the roles are kept too strictly divided there is a chance that the Minister will not get the integrated and thoughtful advice that he or she needs.

\section{Working Together}

In the past, civil servants often resented political advisers. However in the thirty years or so since political advisers first came into UK government this has changed. These days civil servants and advisers tend to work closely together, recognising that a Minister needs a very wide range of advice, both practical and political, if he or she is to make a properly considered decision based on all the available facts. Without the combined advice of civil servants and political advisers the picture is incomplete. Integrated advice that provides a clear overall view, and that is presented as such to the Minister, is therefore the ultimate aim. However, if this is to be achieved, civil servants and political advisers need to work very closely together to prepare and agree policy ideas and advice. Inevitably, this can sometimes be difficult.

In the UK there are no formal arrangements within government ministries for joint working between political advisers and civil servants, and neither the Civil Service Code nor the Code for Special Advisers suggests how this might be best achieved. Civil servants and advisers are expected to find their own way forward. As a political adviser, I found it particularly important to encourage civil servants to discuss issues and problems with me and to be available whenever an civil servant wanted to see me. By doing this I developed a good working relationship with civil servants and I also heard about any problem at the earliest stages. That meant that civil servants and I could together work out the best way to resolve it, sometimes without needing to approach the Minister. The sharing of information and mutual trust is extremely important and a typical day for me would include five or six meetings with civil servants, without the Minister present. This gave us the opportunity to discuss policy issues, current problems or imminent important events and how we expected to deal with them.

Civil servants and I would regularly draft papers and written advice for ministers together, and I would regularly attend meetings in other departments with them where we would together represent the views of our Minister. 


\section{Reconciling Differences}

Civil servants, of course, are usually experts or specialists in certain subjects and many I have worked with have been the country's leading authority on particular areas of public policy. Political advisers, on the other hand, are rarely experts. Occasionally ministers will bring in an expert who is also political - often an academic, but most advisers come from a political background and many have followed their Minister from other departments or worked with them before they were in government.

Tensions between civil servants and political advisers can develop because the ideas and policy solutions civil servants come up with often tend to be determined by very practical factors whereas political advisers may sometimes think more 'creatively' and their ideas may be driven by political considerations such as a Minister's promise to impose tougher prison sentences on burglars, or public concern that too many difficult children are being excluded from school. Of course, civil servants may well be driven by these issues also, but may feel that practical considerations - for example that prisons are too full or that violent children can disrupt a whole school - stand in the way.

So how do we reconcile policy and politics? It seems to me that the first, perhaps obvious, stage is to accept that they are intrinsically linked, as are civil servants and political advisers. Problems usually occur because individuals have failed to understand other viewpoints and have confused 'creative tension' with personal or political opposition. Occasionally, however, either political advisers or civil servants overstep the mark and behave in an unacceptable way.

In the UK there are formal procedures in place to deal with complaints from civil servants about the behaviour of a political adviser. The Code for Special Advisers, under the heading 'Complaints', clearly states:

"Any civil servant who believes that the action of a special adviser goes beyond that adviser's authority, or breaches the Civil Service Code, should raise the matter immediately with the Secretary of the Cabinet or the First Civil Service Commissioner (FCSC), directly or through a senior civil servant" (note: the Secretary of the Cabinet is the head of the Civil Service; the FCSC deals with cases of concern about propriety raised by civil servants under the Civil Service Code).

Protection and redress for civil servants who believe that they are being required by a political adviser to act in way that is improper or unethical is extremely important and no civil servant should ever be compromised or intimidated.

However, there is no equivalent procedure for complaints against civil servants by political advisers, although in theory political advisers could use the same procedure as other civil servants. In the interests of fairness, however, and in order to communicate the clear message that no inappropriate action is ever acceptable, the Code should clearly set out the routes available to a political adviser who has concerns or wishes to report a case of impropriety.

Perhaps the best guide to working together comes from the Civil Service Code's 'Seven Principles of Public Life' which are: selflessness; integrity; objectivity; accountability; openness; honesty; and leadership. If all civil servants and political advisers follow these basic principles, they will not go far wrong. 


\section{The United Kingdom Government's Code of Conduct for Political Advisors}

[Note: The following abbreviated version contains the key provisions of the Code. It should be noted that in the United Kingdom, political advisors are called "special advisers". The powers given to these advisors in sections 9 i and ii have been criticised. The Ministerial Code, which imposes ethical guidelines for ministerial conduct, can be found at http://www.cabinetoffice.gov.uk/propriety and ethics/ministers W/.

1. As set out in the Ministerial Code, the employment of Special Advisers adds a political dimension to the advice and assistance available to Ministers while reinforcing the political impartiality of the permanent Civil Service by distinguishing the source of political advice and support $[\ldots]$.

3. Special Advisers are employed to help Ministers on matters where the work of Government and the work of the Government Party overlap and it would be inappropriate for permanent civil servants to become involved. They are an additional resource for the Minister providing assistance from a standpoint that is more politically committed and politically aware than would be available to a Minister from the Civil Service.

4. The sorts of work a Special Adviser may do if their Minister wants it are:

i. reviewing papers going to the Minister, drawing attention to any aspect which they think has Party political implications, and ensuring that sensitive political points are handled properly. They may give assistance on any aspect of departmental business, including giving advice to their Minister when the latter is taking part in Party political activities;

ii. $\quad$ "devilling" for the Minister, and checking facts and research findings from a Party political viewpoint;

iii. preparing speculative policy papers which can generate long-term policy thinking within the Department, including policies which reflect the political viewpoint of the Minister's Party;

iv. contributing to policy planning within the Department, including ideas which extend the existing range of options available to the Minister with a political viewpoint in mind;

v. liaising with the Party, to ensure that the Department's own policy reviews and analysis take full advantage of ideas from the Party, and encouraging presentational activities by the Party which contribute to the Government's and Department's objectives;

vi. helping to brief Party MPs and officials on issues of Government policy;

vii. liaising with outside interest groups including groups with a political allegiance to assist the Minister's access to their contribution;

viii. speechwriting and related research, including adding Party political content to material prepared by permanent civil servants;

ix. representing the views of their Minister to the media including a Party viewpoint, where they have been authorised by the Minister to do so;

X. providing expert advice as a specialist in a particular field;

xi. attending Party functions (although they may not speak publicly at the Party Conference) and maintaining contact with Party members; 
xii. taking part in policy reviews organised by the Party, or officially in conjunction with it, for the purpose of ensuring that those undertaking the review are fully aware of the Government's views and their Minister's thinking and policy.

\section{Status and conduct as temporary civil servants}

5. Special Advisers are temporary civil servants appointed under Article 3 of the Civil Service Order in Council 1995 [the royal command that, inter alia, governs the appointment of political advisors]. They are exempt from the general requirement that civil servants should be appointed on merit and behave with political impartiality and objectivity so that they may retain the confidence of future governments of a different political complexion. They are otherwise required to conduct themselves in accordance with the Civil Service Code. Their appointment ends at the end of the Administration which appointed them. The responsibility for the management and conduct of Special Advisers, including discipline, rests with the Minister who made the appointment. It is, of course, also open to the Prime Minister to terminate employment by withdrawing his consent to an individual appointment.

6. Special Advisers should conduct themselves with integrity and honesty. They should not deceive or knowingly mislead Parliament or the public. They should not misuse their official position or information acquired in the course of their official duties to further their private interests or the private interests of others. They should not receive benefits of any kind which others might reasonably see as compromising their personal judgment or integrity. They should not without authority disclose official information which has been communicated in confidence in Government or received in confidence from others.

7. Special Advisers should not use official resources for Party political activity. They are employed to serve the objectives of the Government and the Department in which they work. It is this which justifies their being paid from public funds and being able to use public resources, and explains why their participation in party politics is carefully limited. They should act in a way which upholds the political impartiality of civil servants and does not conflict with the Civil Service Code. They should avoid anything which might reasonably lead to the criticism that people paid from public funds are being used for party political purposes[...].

\section{Relations with the Permanent Civil Service}

9. In order to provide effective assistance to Ministers, Special Advisers should work closely with the ministerial team and with permanent civil servants, and establish relationships of confidence and trust. Special Advisers may, on behalf of their Ministers:

(i) convey to officials Ministers' views and work priorities, including on issues of presentation. In doing so, they must take account of civil servants' workloads and any priorities Ministers have set;

(ii) request officials to prepare and provide information and data, including internal analyses and papers;

(iii) hold meetings with officials to discuss the advice being put to Ministers.

(iv) But Special Advisers must not:

(v) ask civil servants to do anything which is inconsistent with their obligations under the Civil Service Code;

(vi) behave towards permanent civil servants in a way which would be inconsistent with the standards set by the employing department for conduct generally;

(vii) have responsibility for budgets or involvement in the award of external contracts; 
(viii) suppress or supplant the advice being prepared for Ministers by permanent civil servants although they may comment on such advice.

10. Where any permanent civil servant has concerns about any request coming from a Special Adviser, they should discuss that concern with the Special Adviser concerned or with their line manager, the Minister's Principal Private Secretary or their Permanent Secretary. If a civil servant feels for whatever reason that he or she is unable to do this then they may wish to raise the concern with a nominated officer within the department or direct with the Head of the Home Civil Service or the First Civil Service Commissioner [...].

\section{Contacts with the Media}

12. Special Advisers are able to represent Ministers' views on Government policy to the media with a degree of political commitment that would not be possible for the permanent Civil Service. Briefing on purely Party political matters should however be handled by the Party machine.

13. All contacts with the news media should be authorised by the appointing Minister and be conducted in accordance with the Guidance on Government Communications. Departmental Directors of Communication are responsible for the overall management of press and publicity operations in their department, and they should therefore be kept informed of Special Advisers' contacts with the news media.

14. Special Advisers must not take public part in political controversy whether in speeches or letters to the Press, or in books, articles or leaflets; must observe discretion and express comment with moderation, avoiding personal attacks; and would not normally speak in public for their Minister or the Department.

\section{Relations with the Government Party}

15. Special Advisers provide assistance to Ministers on the development of Government policy and its presentation. It is in these two areas of activity that Government and Party may overlap.

16. The Civil Service has no monopoly of policy analysis and advice. The Government takes account of views from many sources of which the Government Party is legitimately one. Although public funds and resources must not be used to support the contribution of such views, the Government may need to liaise with the Party, as it does with others, to obtain a full and accurate understanding of the Party's policy analysis and advice.

17. The Government needs to present its policies and achievements to the public in order to aid understanding and so maximise the effectiveness of its policies, and this is a legitimate use of public funds and resources. It would be damaging to the Government's objectives if the Party took a different approach to that of the Government, and the Government therefore needs to liaise with the Party to make sure that Party publicity is factually accurate and consistent with Government policy. To secure this consistency, the Government will also want to make sure that Party MPs and officials are briefed on issues of Government policy.

18. In providing a channel of communication in these areas of overlap, Special Advisers paid from public funds have a legitimate role in support of the Government's interest, which they can discharge with a degree of party political commitment and association which would not be permissible for a permanent civil servant. In all contacts with the Party, Special Advisers must observe normal Civil Service rules on confidentiality unless specifically authorised, in a particular instance, by their appointing Minister.

19. Special Advisers must not take part in the work of the Party's national organisation , and although Special Advisers do not have to resign on the announcement of a General Election it is 
important that those who remain in office to work on Government business take special care to ensure that they do not take any active part in the Election campaign.

20. Where a Special Adviser wishes to undertake work for a political Party which does not arise out of government business they may do this either in their own time, outside office hours, or under a separate contract with the Party, working part-time for the Government (subject to paragraph 19 above). Detailed rules on their involvement in political activities are set out below $[\ldots]$.

\section{Leaving the Civil Service}

28. Under the terms of the Civil Service Code, Special Advisers should continue to observe their duties of confidentiality after they have left Crown employment [i.e. the government's employment] [...]. July 2005.

(The full Code can be found at:

http://www.cabinetoffice.gov.uk/propriety and ethics/special advisers/code.asp) 